\title{
Ruthless Exploiters or Ethical Guardians of the Workforce? Powerful CEOs and their Impact on Workplace Safety and Health
}

\author{
Jesper Haga ${ }^{1} \cdot$ Fredrik Huhtamäki $^{1}$ - Dennis Sundvik ${ }^{1}$ (D)
}

Received: 2 June 2020 / Accepted: 7 January 2021 / Published online: 4 February 2021

(c) The Author(s) 2021

\begin{abstract}
The allocation of resources among different stakeholders is an ethical dilemma for chief executive officers (CEOs). In this study, we investigate the association between CEO power and workplace injuries and illnesses. We use an establishment-level dataset comprising 31,924 establishment-year observations between 2002 and 2011. Our main result shows that employees at firms with structurally powerful CEOs experience fewer workplace injuries and illnesses and days away from work. We reason that CEOs derive a private benefit from low injury and illness rates and that powerful CEOs are better at influencing employees to take workplace safety and health seriously. Additional analyses reveal fewer injuries and illnesses in firms led by CEOs with expertise power. However, increased injuries and illnesses were linked to firms controlled by CEOs with ownership power. Moreover, we find that structurally powerful CEOs mitigate injury and illness differences in relation to geographical proximity to corporate headquarters. We contribute with both research and practical implications on the topics of CEO power and corporate social responsibility (CSR) in general and workplace safety and health in particular.
\end{abstract}

Keywords CEO power $\cdot$ Corporate social responsibility $\cdot$ Real effects $\cdot$ Workplace safety and health

\section{Introduction}

There are numerous contemporary cases where firms with powerful chief executive officers (CEOs) report abysmal safety and health figures. High-profile cases include former BP CEO Tony Hayward, former Tesla chair and current CEO Elon Musk, and Amazon chair and CEO Jeff Bezos. Tony Hayward emphasized economic efficiency and cost control in a manner inconsistent with achieving an enduring safety and health culture (Amernic and Craig 2017). Subsequently, on April 20, 2010, the Deepwater Horizon exploded in the Gulf of Mexico, resulting in 13 casualties and the spillage of 4.9 million oil barrels. Tesla has received a considerable amount of negative press concerning their lackluster injury and illness record, highly pressured workforce, and

Dennis Sundvik

dennis.sundvik@hanken.fi

Jesper Haga

jesper.haga@hanken.fi

Fredrik Huhtamäki

fredrik.huhtamaki@hanken.fi

1 Hanken School of Economics, P.O. Box 287, 65101 Vaasa, Finland poor working environment (Wong 2018; Eidelson and Hull 2019; Ohnsman 2019). Employees at Amazon warehouses have acted as whistle-blowers, organized work stoppages, and drawn attention to the firm's unsafe work practices and injury and illness rates, which are reportedly three times higher than the national average for warehouses (Evans 2019; Sainato 2020). Conversely, powerful CEOs have also been acknowledged for decreasing work-related injuries and illnesses. The late Alcoa chair and CEO Paul O'Neill, for example, emphasized the importance of workplace safety and health and devoted resources to decreasing workdays missed due to injuries and illnesses, claiming "If you want to understand how Alcoa is doing, you need to look at our workplace safety figures" (Wagner 2019).

CEO behaviors influence workplace safety and health (Barling et al. 2002; Mullen 2005; Kelloway et al. 2006; Tucker et al. 2016). The attitudes of top executives are vital to developing corporate social responsibility (CSR) (Fabrizi et al. 2014). In this regard powerful CEOs are particularly interesting, since researchers in accounting, business ethics, finance, and management document that powerful CEOs behave differently than non-powerful CEOs (Adams et al. 2005; Tang et al. 2011; Muttakin et al. 2018; Chu et al. 2019). Even though the safety and health records of 
powerful CEOs have received considerable media attention, and CEO power has been thoroughly studied, systematic research has not been conducted on the association between CEO power and workplace safety and health. In this paper we aim to bridge this gap.

From an agency theory point of view, we reason that CEOs aim to influence workplace safety and health to maximize their utility, for example by making decisions regarding investment in equipment and training, employee workloads, and the firms' safety and health culture. Powerful CEOs have more influence over these decisions than non-powerful CEOs. However, hypothesized relationships between firms with powerful CEOs and workplace injuries and illnesses could be negative (i.e., fewer injuries and illnesses) or positive (i.e., more injuries and illnesses).

Cronqvist et al. (2009) suggest that CEOs can derive utility by paying employees high wages since this creates a better work environment and more loyal employees. In our study, we assume that CEOs might increase their utility by devoting resources to training and equipment, which leads to a low injury and illness frequency. In addition, apart from truly altruistic reasons, low rates of occupational injuries and illnesses may constitute private benefits for CEOs in a reputation building sense (Barnea and Rubin 2010) and act as protection against takeovers (Pagano and Volpin 2005). The process of utility maximization includes an ethical dimension. Ceteris paribus, actions that violate prospective moral norms are less valued than those that follow moral norms (Hirsh et al. 2018). Hence, powerful CEOs can derive private benefits from behaving ethically.

Arguments for a positive relationship between CEO power and workplace injuries and illnesses rely on the perceptions of CEOs that investing in safety and health diverts resources from shareholders, lowers productivity, and makes it harder to fulfill expectations. In general, powerful CEOs create greater internal pressure to exceed earnings targets (Chu et al. 2019). Furthermore, firms that marginally beat analyst forecasts experience greater workplace injuries and illnesses, an increase in employee workload, and abnormal decreases in discretionary expenses (Caskey and Ozel 2017). This suggests that employee well-being is sacrificed owing to external pressure. Considering these arguments, it remains an empirical issue whether CEO power is negatively or positively associated with workplace injuries and illnesses.

To measure the influence of CEO power on workplace injuries and illnesses, we analyze a sample of 31,924 establishment-year observations from 2002 to 2011, with a dataset provided by the United States (U.S.) Occupational Safety and Health Administration (OSHA). In our main analyses, we measure CEO power with two firm-level measures. First, whether the CEO takes a dual role as chairperson or president. Second, by considering the CEOs pay proportional to the five highest paid executives. These two measures capture the structural dimension of power (Finkelstein 1992).

Aside from structural power, Finkelstein (1992) proposed that consideration should be given to ownership, expertise, and prestige power. Thus, we continue to analyze the relationship between these power dimensions and workplace injuries and illnesses. We reason that expertise and prestige power would have a similar relationship with workplace injuries and illnesses as structural power. However, ownership power may have a different relationship, because ownership mitigates agency problems. We also examine the influence of geographical proximity to corporate headquarters since Cronqvist et al. (2009) and Landier et al. (2009) provide evidence that CEOs show favoritism towards employees in proximate establishments. If CEOs derive private benefits from having low injury and illness rates, the influence of powerful CEOs is likely to be stronger in an establishment that is closer to the corporate headquarters. Moreover, Abernethy et al. (2015) suggest that powerful CEOs are able to influence the design of their compensation contracts. Because injury and illness frequency can be a component in CEO compensation, this might affect the relationship we are studying. Thus, we investigate it in a final additional test.

Our study has three main objectives. First, we aim to identify factors that affect workplace safety and health. This is an important topic considering human suffering. The economic and social costs are also substantial. The number of workdays missed due to injuries and illnesses is greater than the number of days missed due to industrial disputes (Wokutch 1990; OECD 2017; OSHA 2018). Approximately 3.5 million workplace injuries occur each year in the U.S. at a greater cost to society than the amount spent on all forms of cancer treatment (Leigh 2011). We also recognize workplace safety and health as an ethical issue based on Sparks and Hunt (1998, p 93) who state that "an ethical issue exists when a decision situation involves one or more alternative courses of action (including no action) that are differentially consistent or inconsistent with some formal or informal ethical rule, code, or norms". Indirectly causing accidents, bodily harm, and incurring socio-economic costs can be directly unethical (Kaptein 2008). While the drivers and mitigating factors of workplace safety and health have been studied comprehensively in other fields (Cantor 2008; Christian et al. 2009; Gyekye and Salminen 2009; Wu et al. 2017; Xia et al. 2017), the interaction between these factors and CEO characteristics remains largely unexplored. Previous business studies show that financially constrained firms (Cohn and Wardlaw 2016) and those that only marginally beat analyst forecasts are associated with higher rates of workplace injuries and illnesses (Caskey and Ozel 2017), while those that receive greater attention from analysts focus more on workplace safety and health (Bradley et al. 2019). Regarding firm efficiency, Wokutch (1990) argue that accidents cause 
disruptions to operations and Choo and Grabowski (2018) show that a good safety and health climate reduces operational stoppages.

Second, we aim to study CEO power and its negative and positive aspects. Bebchuk and Fried (2004) and Morse et al. (2011) suggest that powerful CEOs, in contrast to nonpowerful CEOs, have compensation contracts that are less aligned with shareholders' interests. Thus, powerful CEOs may be a liability to shareholders. However, they may be an asset to other stakeholders. For example, Cronqvist et al. (2009) show that entrenched CEOs pay higher wages to their employees. Our study aims to determine whether leaders use power responsibly and engage in ethical actions that are especially beneficial to a key group of stakeholders-the firms' employees. We use workplace injuries and illnesses to examine whether employees benefit from having a more powerful CEO.

Third, our study is related to the broad business ethics literature on CEO power and engagement in CSR. Prior studies have primarily used aggregate measures of CSR engagement (e.g., using expert ratings from KLD Research and Analytics) and reached mixed conclusions about the relationship between CEO power and CSR (Jiraporn and Chintrakarn 2013; Fabrizi et al. 2014; Jizi et al. 2014; Li et al. 2016; Walls and Berrone 2017). We aim to extend this literature by examining the relation between CEO power and a real component of CSR, workplace injuries and illnesses.

The relevant theory, along with the findings of prior research, and the study's hypothesis are outlined in Chapter 2. Chapter 3 presents the data, methodology, and the descriptive statistics of the study sample. The results are reported in Chapter 4. Finally, Chapter 5 concludes.

\section{Theory and Hypothesis}

\section{Workplace Safety and Health}

Workplace safety and health is an important ethical issue and a vital part of organizational CSR. The consequences of breaches to workplace safety and health are costly in terms of the economic impact and human suffering. Annually, 2.3 million workplace deaths and 300 million workplace accidents are recorded globally (International Labor Organization 2017). In 2015, in the U.S., the number of days away from work due to injuries and illnesses was larger than the number of days away from work due to industrial disputes, 0.9 versus 0.5 days away from work per 100 employees (OECD 2017; OSHA 2018). In the European Union, the economic cost of workplace accidents is estimated to be 3.3\% of total GDP (EU-OSHA 2017), and in the U.S., the societal cost of annual injuries and illnesses (of $\$ 250$ billion) amounts to more than that spent on all forms of cancer treatment (Leigh 2011). ${ }^{1}$ The personal costs are severe when the impact on employees and their families is considered, especially in cases of death or permanent severe disability. Boden and Galizzi (1999) and Boden (2005) find that employees experience earnings losses for several years following a temporary injury or illness. Time away from work due to workplace injuries and illnesses also negatively impacts employee wealth and consumption (Galizzi and Zagorsky 2009). Compensation paid by firms to employees is estimated to amount to only $20.7 \%$ of total costs (Leigh and Marcin 2012), the remainder is borne by employees and their families, insurance carriers, and the government. Consequentially, practitioners and researchers need to understand the underlying drivers and moderating factors of workplace injuries and illnesses.

Firms have several incentives to strive for above average safety and health standards. One reason is that firms themselves face some of the direct economic costs related to injuries and illnesses, but also indirect costs such as higher wage demands (Viscusi 2010). In the U.S., firms that do not comply with safety and health regulations are fined and, in extreme cases, face shutdown (Kniesner and Leeth 2014). More injuries and illnesses also affect the calculation of employees' compensation insurance premiums. Based on non-fatal 2015 U.S. injury and illness data with more than five days away from work, Liberty Mutual Workplace Safety Index reports that the total cost of the most disabling workplace injuries and illnesses was $\$ 58.5$ billion. The general perception of the firm could also be harmed by poor safety and health records. Major accidents draw media attention (Smith et al. 2011), and firms with better CSR ratings incorporating employee safety and health metrics are rewarded with higher valuations (Albuquerque et al. 2019).

An increasing number of business studies is exploring factors that shape the safety and health behaviors of U.S. organizations. Cohn and Wardlaw (2016) find that firms invest in workplace safety and health in the same way in which they invest in assets, and that financial constraints, such as higher leverage and negative cash flow shocks, increase injuries and illnesses. Similarly, Bradley et al. (2018) argue that tax increases lead to more workplace injuries and illnesses. Capital market factors, such as pressure, also shape workplace safety and health. Caskey and Ozel (2017) find higher injury and illness rates for firms that meet or just beat analyst forecasts, which suggests that firms engage in real earnings management by cutting discretionary safety and health investments when under pressure. Having

\footnotetext{
1 The figure of $\$ 250$ billion includes both direct medical costs $(\$ 67$ billion), for example, hospital spending and the cost of treatment by physicians, and indirect costs ( $\$ 183$ billion), such as lost current and future earnings (Leigh 2011).
} 
to disclose rates of injuries and illnesses in financial reports and higher analyst coverage leads to improvements in workplace safety and health (Christensen et al. 2017; Bradley et al. 2019).

There is considerable evidence, albeit mostly based on the use of small questionnaires and qualitative approaches, that organizational leaders play a central role in influencing workplace safety and health. Several studies show that constructive leadership enhances safety and health. For example, Barling et al. (2002) use data from 174 restaurant workers and 164 young workers with diverse jobs and report that transformational leadership was predictive of a climate of enhanced safety and health. Similarly, a study on 158 undergraduate students showed that passive leadership had direct negative safety and health effects (Kelloway et al. 2006). Perceptions of top managerial receptiveness to safety and health was prognostic of willingness to raise safety and health issues among 178 survey participants (Mullen 2005). When leadership is destructive and takes an abusive form, it negatively impacts safety and health, as demonstrated by the findings of a survey of 159 chemical product manufacturing workers in China (Yuan et al. 2020). Using a larger dataset from 54 organizations, Tucker et al. (2016) propose that CEOs in particular impact employee injuries and illnesses through collective social learning. Next, we discuss the specific characteristic of powerful CEOs and its connection with workplace safety and health.

\section{CEO Power}

The concept of power in relation to individuals had been extensively studied in the field of psychology prior to becoming commonplace in business research. Psychology scholars conceptualize power as the capacity to influence others (Thibaut and Kelley 1959; Cartwright 1965; Hambrick 1981) to take actions that they otherwise would not take (Dahl 1957). Power is an abstract concept, which makes it challenging to measure. However, Finkelstein (1992) identifies directly measurable objective indicators of power.

Thus, we study CEO power by considering the four Finkelstein (1992) dimensions of power: structural, ownership, expertise, and prestige power. Structural power is linked to formal hierarchic structures, for example, when a CEO is appointed by the board of directors to lead the firm and is therefore able to exert power over subordinates. Ownership power derives from proprietorship. It increases with stock ownership and is tied to the founder of the firm. A CEO with ownership power is likely to have similar incentives as the other shareholders (Jensen and Meckling 1976; Fama and Jensen 1983). CEOs with expert power have wide-reaching and critical knowledge of organizational processes. This knowledge is a scarce resource and affords authority to CEOs, thereby increasing their capacity to exert their will.
Finally, prestige power pertains to reputation and bestows power on CEOs through the absorption of uncertainty from the institutional environment (Finkelstein 1992).

Power produces overconfidence, diminished risk aversion, and increased insensitivity to others (Pfeffer 2010). Holders of power are better at setting and achieving goals than their peers (Galinsky et al. 2008). In an experimental study, Joshi and Fast (2013) argue that experiencing power decreases temporal discounting, leading to a more long-term oriented approach.

The impact of CEO power on the firm may be negative as well as positive. A negative aspect is that power enables the CEO to obtain private benefits, at the expense of shareholder value. Barkema and Pennings (1998) find that powerful CEOs receive more compensation, while Bebchuk and Fried (2004) add that the compensation these CEOs receive are less linked to the performance of the firm. Morse et al. (2011) find that powerful CEOs are more likely to rig incentive contracts. Furthermore, CEOs with much power are less likely to be challenged after poor performance (Allen and Panian 1982). The literature shows that a positive aspect of power concentration is a quicker decision-making process (Finkelstein and D'Aveni 1994) as it leads to a timely response to challenges and unanticipated changes in market conditions. Similarly, firms headed by powerful CEOs experience higher relative valuation in industries that operate in high-demand product markets, which suggests that powerful CEOs are particularly valued in firms that require rapid decision-making (Li et al. 2019). Finally, Tang et al. (2011) suggest that powerful CEOs are more likely to engage in risk-taking, and as a result the performance of their firms is more extreme. Adams et al. (2005) find that firms with powerful CEOs experience more variability in stock returns, signifying that powerful CEOs act unilaterally, leading to more pronounced judgment errors compared to less powerful CEOs who involve other directors in the decision-making process to a greater extent.

The business literature has extensively assessed the association between CEO power and CSR-related activity. The majority of studies reported a negative relationship between CEO power and CSR, however, there is a lack of consensus in this regard. In this literature, Li et al. (2016) show that CEOs with more structural power engage in fewer CSR activities. Muttakin et al. (2018) study CEO power and CSR disclosure and argue that more powerful CEOs are primarily concerned about their own interests and place less emphasis on the needs of other stakeholders. In line with the arguments, Muttakin et al. (2018) find a negative association between CEO power and CSR disclosure. However, Jiraporn and Chintrakarn (2013) argue that the relation is non-monotonic, and that an increase in power is only associated with a decrease in CSR activity at high levels of CEO power. Notably, all these studies, except for the study by Muttakin 
et al. (2018), relied on the KLD (now called the MSCI) database to quantify CSR. While the KLD database was initially recognized as the most optimal information available to researchers studying CSR in the U.S. (Hillman and Klein 2001), a major limitation is that it is an aggregate measure of CSR. In contrast to the findings of other studies, Walls and Berrone (2017) find that informal CEO power is associated with a lower aggregated damage score that focuses on environmental activities.

Prior ethics studies such as Jizi et al. (2014) and Fabrizi et al. (2014) also find a positive relationship between CEO power and different CSR aspects. Jizi et al. (2014) show that firms where the same person is serving as CEO and chairperson have more CSR disclosure. Further, Fabrizi et al. (2014) show that CEO power is positively associated with EIRIS measurement of employee-oriented CSR. The EIRIS data has similar limitations as KLD data, both measure CSR at an aggregated level. As a result, only concerns regarding safety and health systems can be verified in the prior literature on ethics, which is not necessarily indicative of de facto safety and health performance (i.e., recorded workplace injuries and illnesses).

\section{Hypothesis Development}

By definition, powerful CEOs are able to affect firm strategy to a greater extent than CEOs with less power (Finkelstein 1992; Adams et al. 2005). However, it is unclear whether the association between CEO power and the frequency of injuries and illnesses is negative or positive.

From an agency theory point of view, managers will influence workplace safety and health to maximize their utility (Friedman 1970; Jensen and Meckling 1976). We believe that a low injury and illness frequency may constitute a private benefit for a manager, because a low injury and illness frequency, in a similar way as high wages (Cronqvist et al. 2009), can yield a better work environment and a more loyal workforce. Investments in workplace safety and health, resulting in a low injury and illness frequency may nurture an alliance between the CEO and the employees, which reduces risk of potential hostile takeovers, since the workforce will lobby and demonstrate against any hostile takeover to protect their benefits (Pagano and Volpin 2005). A low injury and illness frequency can also be used for personal reputation building (Barnea and Rubin 2010). Furthermore, Hirsh et al. (2018) argue that actions fulfilling moral norms are utility creating for the individual. Given that the moral norms favor a low frequency of workplace injuries and illnesses, a powerful CEO may extract private utility from investing in workplace safety and health. Alternatively, powerful CEOs may be more effective at policy implementation. Huang et al. (2007) provide survey evidence concerning decision makers' attitudes in mid-to-large sized firms regarding the value of workplace safety and health and find that the participants have a positive attitude towards devoting resources to improving workplace safety and health. ${ }^{2} \mathrm{By}$ contrast, Zierold et al. (2012) provide evidence of employees believing that safety and health training is important, but that they personally don't need it. Furthermore, Dahl (1957) argues that power is the ability to make others do things they otherwise would not do. Thus, a powerful CEO could be more able to influence employees to take workplace safety and health seriously.

Arguments can also be made, that the association between CEO power and injury and illness frequency is positive. Chu et al. (2019) find that powerful CEOs create more internal pressure to beat earnings targets, and since Mullen (2005) finds evidence that pressure is a key factor in explaining unsafe work behavior, a case can be made that CEO power could be positively related to workplace injuries and illnesses. Caskey and Ozel (2017) show that firms marginally beating analyst forecasts have more workplace injuries and illnesses and that these firms are associated with increases in both employee workload and abnormal reductions in discretionary expenses, suggesting that employee wellbeing is sacrificed under pressure. Finally, insensitivity to others is a known trait of powerful CEOs (Pfeffer 2010), which makes it easier for them to disregard employees' safety and health.

Based on these arguments, there is a need to empirically determine the relationship between CEO power and workplace injuries and illnesses. To this end, we form the following nondirectional hypothesis:

H1: There is an association between CEO power and workplace injuries and illnesses.

\section{Research Design}

\section{Dataset}

To construct the dataset, we combine data on public firms in Compustat and ExecuComp with data on establishment-level workplace injuries and illnesses from the Bureau of Labor Statistics' annual Survey of Occupational Injuries and Illnesses in the U.S. ${ }^{3}$ The surveys were conducted under the OSHA Data Initiative program, which began in 1996 and was terminated in 2011 due to funding cuts. The OSHA data include statistics on work-related injuries and illnesses for a

\footnotetext{
2 Most participants estimated that every dollar invested in workplace safety and health would return at least two dollars due to increased productivity and reduced costs.

3 We thank Dave Schmidt, OSHA, Office of Statistical Analysis, for providing us with data on workplace injuries and illnesses.
} 
large variety of private-sector establishments. ${ }^{4}$ In addition to injuries and illnesses, the OSHA data also contain information about the establishment's name and location, number of employees, number of hours worked, and any unusual events that occurred during the year. Each year, OSHA selects a number of establishments to be surveyed, focusing on industries that are classified as high-hazard (e.g., manufacturing, transportation, and home improvement stores). In order to select establishments OSHA uses an adjusted random sampling method. The adjustments to the random sampling method ensure that potential high-hazard establishments are surveyed at least once every 3 years. Moreover, establishments that have failed in the communication with OSHA or have high injury and illness rates are more likely to be surveyed again.

We use OSHA data from 2002 to 2011, which contain 649,925 establishment-year observations for listed and unlisted firms. ${ }^{5}$ We follow Caskey and Ozel (2017) when matching the OSHA data with Compustat data. ${ }^{6}$ We remove firms and establishments from financial and utility industries (SIC 6000-6999 and SIC 4900-4999). After these two initial steps we have 71,649 establishment-year observations from 1061 firms. We merge the dataset with data from ExecuComp, yielding a dataset of 68,784 establishment-year observations (from 1011 firms). We also remove observations with missing data for any of our variables in the main regression (see description of Eq. 1) and establishments with fewer than 10 employees. The final sample contains 31,924 establishment-year observations from 319 firms.

Table 1 presents the sample composition by industry, state and year. Panel A of Table 1 reports establishmentyear observations and mean total case rate (TCR) by the Fama-French 12 industries. TCR, our main dependent variable, is calculated for each establishment by dividing workrelated injuries and illnesses by working hours and multiplying the quotient with $200,000 .^{7}$ The Fama-French industry Other (e.g., establishments from transportation, mines and construction) has the highest average TCR (11.95). The

\footnotetext{
$\overline{4}$ OSHA defines injuries and illnesses as "Any work-related fatality; any work-related injury or illness that results in loss of consciousness, days away from work, restricted work, or transfer to another job; any work-related injury or illness requiring medical treatment beyond first aid; any work-related diagnosed case of cancer, chronic irreversible disease, fractured or cracked bones or teeth, and punctured eardrums; work-related cases involving needlesticks and sharps injuries, medical removal, hearing loss, and tuberculosis" (OSHA, Retrieved January 1, 2021, from https://www.osha.gov/recordkeeping/).

5 We use data from 2002 onwards because OSHA revised and improved the guidelines for data collection process in 2001.

${ }^{6}$ Gratitude is extended to Caskey and Ozel (2017) for making their link between OSHA establishments and gvkey publicly available.

7 The figure of 200,000 represents the working hours for 100 employees working $40 \mathrm{~h}$ a week for 50 weeks.
}

industry with the most establishment-year observations is Wholesale/Retail. Panel B of Table 1 displays the sample by state. California (3131 observations) and Texas (2477 observations) have most establishments. In our sample, establishments located in West Virginia have the highest average TCR (11.04). Panel C of Table 1 shows the annual evolvement of observations and the TCR. It is evident that average TCR has decreased over time. While we note a smaller number of observations in 2009 and 2011, our results are not sensitive to removing these years.

\section{Regression Models and Variables}

Most of our analyses are estimated with establishment-level data using TCR as our dependent variable. ${ }^{8}$ According to Finkelstein (1992), structural power can be captured with formal titles and relative compensation. Thus, the independent variable of interest is either CEO duality or CEO pay slice in our main analyses. CEO duality is an indicator variable, taking the value 1 if the CEO of the firm is also the chairperson of the board of directors. CEO duality indicates that the CEO has structural power over both top executives and the board. The second measure of structural CEO power, CEO pay slice, is measured as the proportion of the aggregated firm's top-five executive compensation obtained by the CEO. Bebchuk et al. (2011) suggest that one of the reasons for higher CEO pay slice is that CEOs with much power can influence their own salary.

In our main analyses, we estimate the following OLS regression:

TCR $_{e, t}=\alpha_{0}+\beta_{1}$ CEOPower $_{e, t}+\beta$ Controls $_{e, t}+\varepsilon_{e, t}$

where $T C R_{e, t}$ is the TCR for establishment e at time t. ${ }^{9}$ In addition to the independent variable of interest, we also include a set of control variables. We control for CEO characteristics by including the age of the CEO (LnAge), the length of CEO tenure (LnTenure) and a dummy variable for whether the CEO is a female (Female CEO). To our knowledge no study has linked CEO age or gender to the number of workplace injuries and illnesses, however, these $\mathrm{CEO}$ characteristics are related to $\mathrm{CEO}$ behavior. Empirical studies show that firms governed by older and female CEOs hold less debt, indicating that these types of CEOs are less risk-taking (Serfling 2014; Faccio et al. 2016).

In addition to the CEO characteristics, we include establishment-level controls based on the OSHA data following

\footnotetext{
${ }^{8}$ Our results also hold using firm-level data.

${ }^{9}$ In untabulated regressions, we estimate Eq. (1) as a poisson regression and a negative binomial regression, since the dependent variable, TCR, is a count variable. The results are quantitatively and qualitatively similar.
} 
Table 1 Sample composition

\begin{tabular}{|c|c|c|}
\hline Fama-French 12-industry & Est.-year Obs & Mean TCR \\
\hline \multicolumn{3}{|l|}{ Panel A: by industry } \\
\hline Business equipment & 763 & 2.54 \\
\hline Chemicals/allied products & 301 & 2.00 \\
\hline Consumer durables & 1877 & 8.06 \\
\hline Consumer nondurables & 4310 & 9.10 \\
\hline Energy & 169 & 2.25 \\
\hline Healthcare & 1417 & 9.09 \\
\hline Manufacturing & 6014 & 4.49 \\
\hline Other & 4887 & 11.95 \\
\hline Telephone/television transmission & 246 & 5.21 \\
\hline Wholesale/retail & 11,940 & 7.14 \\
\hline State & Est.-year Obs & Mean TCR \\
\hline \multicolumn{3}{|l|}{ Panel B: by state } \\
\hline Alaska & 33 & 9.95 \\
\hline Alabama & 504 & 6.52 \\
\hline Arkansas & 489 & 6.41 \\
\hline Arizona & 246 & 7.51 \\
\hline California & 3131 & 7.84 \\
\hline Colorado & 561 & 8.61 \\
\hline Connecticut & 468 & 8.76 \\
\hline Washington DC & 15 & 2.95 \\
\hline Delaware & 145 & 8.51 \\
\hline Florida & 1752 & 8.04 \\
\hline Georgia & 1391 & 6.84 \\
\hline Hawaii & 79 & 8.99 \\
\hline Iowa & 391 & 8.80 \\
\hline Idaho & 168 & 9.41 \\
\hline Illinois & 1546 & 7.05 \\
\hline Indiana & 897 & 7.53 \\
\hline Kansas & 358 & 7.12 \\
\hline Kentucky & 653 & 9.43 \\
\hline Louisiana & 408 & 5.74 \\
\hline Massachusetts & 726 & 7.93 \\
\hline Maryland & 531 & 6.91 \\
\hline Maine & 158 & 10.59 \\
\hline Michigan & 1373 & 8.13 \\
\hline Minnesota & 564 & 7.25 \\
\hline Missouri & 737 & 8.10 \\
\hline Mississippi & 364 & 6.40 \\
\hline Montana & 97 & 8.66 \\
\hline North Carolina & 1621 & 7.17 \\
\hline North Dakota & 82 & 6.42 \\
\hline Nebraska & 215 & 7.56 \\
\hline New Hampshire & 231 & 8.87 \\
\hline New Jersey & 967 & 7.64 \\
\hline New Mexico & 132 & 8.80 \\
\hline Nevada & 199 & 8.72 \\
\hline New York & 1196 & 7.58 \\
\hline Ohio & 1963 & 6.93 \\
\hline
\end{tabular}


Table 1 (continued)

\begin{tabular}{|c|c|c|c|}
\hline State & \multicolumn{2}{|c|}{ Est.-year Obs } & Mean TCR \\
\hline Oklahoma & \multicolumn{2}{|c|}{365} & 9.03 \\
\hline Pennsylvania & \multicolumn{2}{|c|}{1569} & 8.21 \\
\hline Rhode Island & \multicolumn{2}{|c|}{89} & 8.07 \\
\hline South Carolina & \multicolumn{2}{|c|}{5} & 2.61 \\
\hline South Dakota & \multicolumn{2}{|c|}{79} & 8.16 \\
\hline Tennessee & \multicolumn{2}{|c|}{991} & 7.19 \\
\hline Texas & \multicolumn{2}{|c|}{2477} & 6.82 \\
\hline Utah & \multicolumn{2}{|c|}{259} & 7.70 \\
\hline Virginia & \multicolumn{2}{|c|}{550} & 6.12 \\
\hline Vermont & \multicolumn{2}{|c|}{69} & 8.96 \\
\hline Wisconsin & \multicolumn{2}{|c|}{824} & 7.28 \\
\hline West Virginia & \multicolumn{2}{|c|}{256} & 11.04 \\
\hline Year & Est.-year Obs & Firm-year Obs & Mean TCR \\
\hline \multicolumn{4}{|l|}{ Panel C: by year } \\
\hline 2002 & 2902 & 113 & 10.97 \\
\hline 2003 & 3875 & 115 & 9.14 \\
\hline 2004 & 3057 & 139 & 9.94 \\
\hline 2005 & 4402 & 165 & 8.35 \\
\hline 2006 & 2867 & 165 & 7.94 \\
\hline 2007 & 3912 & 190 & 6.94 \\
\hline 2008 & 4480 & 192 & 5.28 \\
\hline 2009 & 1969 & 143 & 5.56 \\
\hline 2010 & 3545 & 158 & 4.94 \\
\hline 2011 & 915 & 138 & 6.10 \\
\hline
\end{tabular}

This table reports the sample composition. Panel A shows the number of observations and mean TCR by Fama-French 12 industries. Panel B shows the number of observations and mean TCR by state. Panel C shows the number of observations and mean TCR by year. TCR is the number of work-related injury and illness cases divided with the number of hours worked multiplied with 200,000

Caskey and Ozel (2017) in the form of hours per employee (Hours per employee), establishment workforce by taking $\log$ of the number of employees (Establishment size), strikes or lockouts (Strike), shutdowns or layoffs (Shutdown), seasonal work (Seasonal), and natural disasters or adverse weather conditions (Disaster) that could affect the injury and illness frequency. Based on Compustat data, we also follow Caskey and Ozel (2017) when controlling for firm size by including the log value of total assets (LnAssets), for capital structure by dividing total debt by total assets (Leverage), for growth opportunities by using capital expenditures divided by total assets (Capex/Assets) and market value of equity to book value (Market/Book), for asset turnover by dividing sales by total assets (Sales/Assets), and for tangibility by dividing property, plant and equipment by total assets (PPE/Assets). In addition to these control variables, we include Year, Industry, and State fixed-effects to control for unobservable heterogeneities. We provide definitions of all variables in Appendix in Table 10.

\section{Descriptive Statistics}

Table 2 reports descriptive statistics for establishment-level and firm-level variables. Panel A presents summary statistics for establishment-level variables where the average TCR is 7.58. We also report the summary statistics for number of days away from work (DAW) and death case rate (DCR), both variables are calculated by taking the number of occurrences divided by number of hours worked and multiplying the quotient by 200,000 . In the sample, average DAW and DCR is 195.49 and 0.003, respectively. An average establishment has 301.23 employees that are working $1937.64 \mathrm{~h}$ a year. Establishment shutdowns impact 7\% of establishment-year observations. Panel B of Table 2 shows summary statistics for firm-level variables. In the sample, the CEO serves as the chairperson in $26 \%$ of the firm-year observations. CEOs on average receive a compensation corresponding to $40 \%$ of the aggregated compensation of the top-five executives. For our firm-year observations the average age and tenure of a CEO is 56.15 and 5.57 years, respectively. Only $2 \%$ of our firmyear observations has a female CEO. Overall, the summary 
Table 2 Descriptive statistics

\begin{tabular}{lrrlllr}
\hline & Observations & Mean & Median & p25 & p75 & St.Dev \\
\hline Panel A: establishment statistics & & & & & & \\
TCR & 31,924 & 7.58 & 5.93 & 2.73 & 10.56 & 6.66 \\
DAW & 31,924 & 195.49 & 115.38 & 23.20 & 275.34 & 238.58 \\
DCR & 31,924 & 0.00 & 0.00 & 0.00 & 0.00 & 0.08 \\
Hours per employee & 31,924 & 1937.64 & 1990.30 & 1766.69 & 2085.14 & 320.21 \\
Number of employees & 31,924 & 301.23 & 133.00 & 85.00 & 227.00 & 750.62 \\
Establishment size & 31,924 & 5.02 & 4.89 & 4.44 & 5.42 & 0.97 \\
Strike & 31,924 & 0.00 & 0.00 & 0.00 & 0.00 & 0.04 \\
Shutdown & 31,924 & 0.07 & 0.00 & 0.00 & 0.00 & 0.25 \\
Seasonal & 31,924 & 0.04 & 0.00 & 0.00 & 0.00 & 0.19 \\
Disaster & 31,924 & 0.01 & 0.00 & 0.00 & 0.00 & 0.07 \\
Panel B: firm statistics & & & & & & \\
CEO duality & 1518 & 0.28 & 0 & 0 & 1 & 0.45 \\
CEO pay slice & 1518 & 0.40 & 0.42 & 0.34 & 0.47 & 0.11 \\
Age & 1518 & 56.15 & 56.00 & 52.00 & 60.00 & 5.90 \\
LnAge & 1518 & 4.02 & 4.03 & 3.95 & 4.09 & 0.11 \\
Tenure & 1518 & 5.57 & 4.00 & 2.00 & 7.00 & 5.35 \\
LnTenure & 1518 & 1.59 & 1.61 & 1.10 & 2.08 & 0.79 \\
Female CEO & 1518 & 0.02 & 0 & 0 & 0 & 0.13 \\
LnAssets & 1518 & 8.94 & 8.80 & 8.02 & 9.73 & 1.28 \\
Leverage & 1518 & 0.23 & 0.22 & 0.13 & 0.31 & 0.15 \\
PPE/assets & 1518 & 0.29 & 0.26 & 0.16 & 0.40 & 0.17 \\
Sales/assets & 1518 & 1.37 & 1.15 & 0.86 & 1.60 & 0.83 \\
Capex/assets & 1518 & 0.05 & 0.04 & 0.03 & 0.06 & 0.04 \\
Market/book & 1518 & 1.75 & 1.51 & 1.20 & 2.03 & 0.85 \\
\hline
\end{tabular}

This table reports summary statistics. Panel A reports summary statistics for establishment-level variables and Panel B reports summary statistics for all firm-level variables. We provide definitions of all variables in Appendix in Table 10

statistics for the CEO characteristics are reasonable and the summary statistics for establishment- and firm-level variables are comparable to what Caskey and Ozel (2017) reported.

Table 3 presents correlations between TCR and the CEO and firm-level control variables. The correlation between our structural CEO power measures (CEO duality and CEO pay slice) and TCR is negative (-0.10 and -0.12$)$. CEO duality and CEO pay slice are positively correlated (0.18) with each other. Table 3 also shows a negative correlation between TCR and the other three CEO characteristics LnAge, LnTenure, and Female CEO. Regarding firm-level control variables, we find that TCR is positively correlated with Leverage, PPE/Assets and Sales/Assets.

\section{Results}

\section{Main Results}

Table 4 reports the results of the main analyses. Columns (1) to (3) show the association between CEO duality and workplace injuries and illnesses. We begin by regressing TCR on CEO duality, Year, Industry, and State fixed-effects. In Column (1), the coefficient for CEO duality is significantly negative (coeff. $-1.71, t$-stat -3.75 ). The negative relationship holds with control variables in Column (2), where we report the results for Eq. (1). These negative coefficients are supportive of the notion that firms with structurally more powerful CEOs have fewer workplace injuries and illnesses. The economic magnitude is also substantial, firms governed by a CEO also serving as chairperson have 1.75 fewer injuries and illnesses per 100 full time employees (Column 2). The moderate change in the coefficient between the regressions is an indication of a robust result. Furthermore, Column (2) also shows that firms with older CEOs have fewer workplace injuries and illnesses. We find results consistent with Cohn and Wardlaw (2016), namely, that firms with higher leverage have a higher injury and illness frequency. The coefficients for the dummy variables Strike and Shutdown are positive and significant. The $R$-square for Eq. (1) is 0.310, however, the majority of the explained variation comes from Year, Industry, and State fixed-effects. 
Table 3 Correlations

(1)

(2)

(3)

(4)

(5)

(6)

(7)

(8)

(9)

(10)

(11)

(12)

(13) (14) (15)

\begin{tabular}{|c|c|c|c|c|c|c|c|c|c|c|c|c|c|c|c|}
\hline (1) TCR & 1.00 & & & & & & & & & & & & & & \\
\hline (2) DAW & 0.77 & 1.00 & & & & & & & & & & & & & \\
\hline (3) DCR & -0.01 & 0.00 & 1.00 & & & & & & & & & & & & \\
\hline (4) CEO duality & -0.10 & -0.07 & 0.02 & 1.00 & & & & & & & & & & & \\
\hline (5) CEO pay slice & -0.12 & -0.10 & 0.02 & 0.18 & 1.00 & & & & & & & & & & \\
\hline (6) LnAge & -0.09 & -0.08 & 0.02 & -0.03 & 0.10 & 1.00 & & & & & & & & & \\
\hline (7) LnTenure & -0.09 & -0.06 & 0.04 & 0.04 & 0.09 & 0.36 & 1.00 & & & & & & & & \\
\hline (8) Female CEO & -0.01 & 0.04 & 0.00 & -0.01 & -0.03 & -0.05 & -0.09 & 1.00 & & & & & & & \\
\hline (9) Hours per employee & -0.25 & -0.21 & 0.03 & 0.01 & 0.07 & -0.01 & 0.00 & 0.04 & 1.00 & & & & & & \\
\hline (10) LnAssets & -0.19 & -0.08 & 0.02 & 0.03 & 0.02 & 0.08 & -0.01 & 0.03 & 0.02 & 1.00 & & & & & \\
\hline (11) Leverage & 0.05 & 0.05 & 0.05 & -0.03 & 0.01 & 0.00 & 0.03 & 0.00 & 0.00 & 0.07 & 1.00 & & & & \\
\hline (12) PPE/assets & 0.13 & 0.20 & 0.02 & -0.01 & -0.06 & 0.03 & 0.00 & 0.05 & -0.10 & 0.00 & 0.06 & 1.00 & & & \\
\hline (13) Sales/assets & 0.29 & 0.26 & -0.01 & 0.03 & -0.05 & 0.01 & -0.03 & 0.08 & -0.07 & -0.25 & -0.26 & 0.13 & 1.00 & & \\
\hline (14) Capex/assets & 0.08 & 0.10 & 0.02 & -0.05 & -0.05 & 0.00 & 0.06 & 0.05 & -0.04 & -0.09 & -0.21 & 0.60 & 0.22 & 1.00 & \\
\hline (15) Market/book & -0.07 & -0.04 & -0.01 & -0.03 & -0.01 & -0.07 & -0.08 & 0.02 & 0.00 & -0.01 & -0.35 & -0.04 & 0.08 & 0.25 & 1.00 \\
\hline
\end{tabular}

This table reports a correlation matrix for firm-level variables and establishment-level variables aggregated to the firm-level (TCR, DAW, DCR and Hours per employee). We provide definitions of all variables in Appendix in Table 10

In Column (3) of Table 4, we further examine whether the negative association between CEO duality and TCR appear with firm-level data. We find that the coefficient for CEO duality continues to be negative, however, smaller in magnitude and insignificant (coef. - 0.52, $t$-stat - 1.51). In Column (4) to (6) of Table 4, we use CEO pay slice as our measure of structural CEO power. Column (5) reports the results for Eq. (1) where we find a significantly negative coefficient for CEO pay slice (coeff. $-4.03, t$-stat -1.70 ). The coefficient for CEO pay slice is also economically significant, indicating that each ten percentage increase in CEO compensation in relation to the top-five executives is associated with 0.403 fewer injuries and illnesses per year per 100 full time employees. In Column (6), we report firm-level results for the association between CEO pay slice and TCR. The coefficient for CEO pay slice is smaller for the firm-level results than in the establishment-level results, however the statistically significant results hold. Taken together, the results in Table 4 provides support for our hypothesis that there is an association between structural CEO power and workplace injuries and illnesses. We find a negative association, indicating that firms with structurally more powerful CEOs have lower rates of workplace injuries and illnesses.

The data from OSHA gives us the possibility to vary the way we measure workplace safety and health breaches. In Table 5, we examine whether our results are prevalent also when studying the number of days away from work due to injuries and illnesses (DAW) and the most extreme sign of poor workplace safety and health, deaths (DCR). Column (1) and (2) of Table 5 reports the results for Eq. (1) with DAW as the dependent variable. In Column (1), CEO duality has a negative and significant coefficient (coeff. $-39.77, t$-stat - 4.46), suggesting that employees in firms where the CEO is serving as chairperson have fewer days away from work due to injuries and illnesses. Column (2) shows that CEO pay slice is also negatively related to DAW, however only significant at the $10 \%$ level. We again find evidence suggesting that the employees of firms with older CEOs experience fewer days away from work due to injuries and illnesses. Shutdowns and disasters are positively associated with the number of days away from work. In Column (3) and (4) of Table 5, DCR is the dependent variable. In neither of the columns is the coefficient for our power measure significant and the coefficient is only negative when CEO duality is used as a measure of structural CEO power.

As Tables 4 and 5 show a significantly negative association between structural CEO power and workplace injuries and illnesses, we next attempt to more precisely identify the connection between the variables. By utilizing state-wide changes in non-compete laws as exogenous changes in labor markets that increases $\mathrm{CEO}$ power, we examine whether CEO power causes decreases in injuries and illnesses. In this regard, we follow Ewens and Marx (2018) who describe that the power of CEOs is increased (decreased) when noncompete enforceability has been strengthened (weakened) since the supply of potential CEO replacements is affected. During our sample period, five states amended their state laws in order to strengthen the enforceability of non-compete laws: Ohio (2004), Idaho (2008), Wisconsin (2009), Georgia (2010), and Illinois (2011). We expect the CEOs of firms located in these states to experience a positive power shock, which would decrease workplace injuries and illnesses 
Table 4 Main regression results

\begin{tabular}{|c|c|c|c|c|c|c|}
\hline & TCR & TCR & TCR & TCR & TCR & TCR \\
\hline CEO duality & $\begin{array}{l}-1.71 * * * \\
(-3.75)\end{array}$ & $\begin{array}{l}-1.75^{* * *} \\
(-4.33)\end{array}$ & $\begin{array}{l}-0.52 \\
(-1.51)\end{array}$ & & & \\
\hline CEO pay slice & & & & $\begin{array}{l}-4.24 * * \\
(-2.35)\end{array}$ & $\begin{array}{l}-4.03 * \\
(-1.70)\end{array}$ & $\begin{array}{l}-2.37 * * \\
(-2.05)\end{array}$ \\
\hline LnAge & & $\begin{array}{l}-6.11 * * * \\
(-4.38)\end{array}$ & $\begin{array}{l}-2.14 \\
(-1.25)\end{array}$ & & $\begin{array}{l}-5.59 * * * \\
(-3.91)\end{array}$ & $\begin{array}{l}-1.90 \\
(-1.12)\end{array}$ \\
\hline LnTenure & & $\begin{array}{l}0.18 \\
(0.97)\end{array}$ & $\begin{array}{l}-0.14 \\
(-0.79)\end{array}$ & & $\begin{array}{l}0.24 \\
(0.91)\end{array}$ & $\begin{array}{l}-0.13 \\
(-0.70)\end{array}$ \\
\hline Female CEO & & $\begin{array}{l}-0.28 \\
(-0.44)\end{array}$ & $\begin{array}{l}-1.35 \\
(-1.20)\end{array}$ & & $\begin{array}{l}-0.51 \\
(-0.67)\end{array}$ & $\begin{array}{l}-1.43 \\
(-1.22)\end{array}$ \\
\hline Hours per employee & & $\begin{array}{l}-0.00 * * * \\
(-3.88)\end{array}$ & $\begin{array}{l}-0.00 * * * \\
(-2.77)\end{array}$ & & $\begin{array}{l}-0.00 * * * \\
(-3.87)\end{array}$ & $\begin{array}{l}-0.00 * * * \\
(-2.80)\end{array}$ \\
\hline Establishment size & & $\begin{array}{l}0.09 \\
(0.64)\end{array}$ & & & $\begin{array}{l}0.08 \\
(0.55)\end{array}$ & \\
\hline LnAssets & & $\begin{array}{l}-0.17 \\
(-0.67)\end{array}$ & $\begin{array}{l}-0.18 \\
(-0.58)\end{array}$ & & $\begin{array}{l}-0.15 \\
(-0.55)\end{array}$ & $\begin{array}{l}-0.19 \\
(-0.60)\end{array}$ \\
\hline Leverage & & $\begin{array}{l}3.53^{*} \\
(1.80)\end{array}$ & $\begin{array}{l}1.04 \\
(0.62)\end{array}$ & & $\begin{array}{l}3.48 * \\
(1.74)\end{array}$ & $\begin{array}{l}1.06 \\
(0.62)\end{array}$ \\
\hline PPE/assets & & $\begin{array}{l}0.26 \\
(0.17)\end{array}$ & $\begin{array}{l}-3.18 * * \\
(-2.05)\end{array}$ & & $\begin{array}{l}0.40 \\
(0.26)\end{array}$ & $\begin{array}{l}-3.38 * * \\
(-2.18)\end{array}$ \\
\hline Sales/assets & & $\begin{array}{l}0.01 \\
(0.03)\end{array}$ & $\begin{array}{l}0.99 * * \\
(2.56)\end{array}$ & & $\begin{array}{l}-0.21 \\
(-0.44)\end{array}$ & $\begin{array}{l}0.99 * * \\
(2.58)\end{array}$ \\
\hline Capex/assets & & $\begin{array}{l}8.62 \\
(0.81)\end{array}$ & $\begin{array}{l}-2.19 \\
(-0.44)\end{array}$ & & $\begin{array}{l}7.82 \\
(0.70)\end{array}$ & $\begin{array}{l}-1.99 \\
(-0.40)\end{array}$ \\
\hline Market/book & & $\begin{array}{l}-0.00 \\
(-0.01)\end{array}$ & $\begin{array}{l}-0.64 * * * \\
(-3.18)\end{array}$ & & $\begin{array}{l}-0.03 \\
(-0.11)\end{array}$ & $\begin{array}{l}-0.65 * * * \\
(-3.19)\end{array}$ \\
\hline Strike & & $\begin{array}{l}1.14 \\
(0.93)\end{array}$ & & & $\begin{array}{l}0.83 \\
(0.63)\end{array}$ & \\
\hline Shutdown & & $\begin{array}{l}0.68^{*} \\
(1.95)\end{array}$ & & & $\begin{array}{l}0.61 * \\
(1.79)\end{array}$ & \\
\hline Seasonal & & $\begin{array}{l}-0.02 \\
(-0.03)\end{array}$ & & & $\begin{array}{l}-0.26 \\
(-0.30)\end{array}$ & \\
\hline Disaster & & $\begin{array}{l}1.32 * \\
(1.77)\end{array}$ & & & $\begin{array}{l}1.36^{*} \\
(1.82)\end{array}$ & \\
\hline Constant & $\begin{array}{l}8.07 * * * \\
(4.20)\end{array}$ & $\begin{array}{l}41.14 * * * \\
(7.03)\end{array}$ & $\begin{array}{l}20.81 * * * \\
(3.26)\end{array}$ & $\begin{array}{l}8.65 * * * \\
(4.33)\end{array}$ & $\begin{array}{l}39.82 * * * \\
(6.67)\end{array}$ & $\begin{array}{l}20.44 * * * \\
(3.23)\end{array}$ \\
\hline Industry FE & YES & YES & YES & YES & YES & YES \\
\hline Year FE & YES & YES & YES & YES & YES & YES \\
\hline State FE & YES & YES & NO & YES & YES & NO \\
\hline R-squared & 0.268 & 0.310 & 0.418 & 0.263 & 0.304 & 0.419 \\
\hline Level & Est.-year & Est.-year & Firm-year & Est.-year & Est.-year & Firm-year \\
\hline Observations & 31,924 & 31,924 & 1518 & 31,924 & 31,924 & 1518 \\
\hline
\end{tabular}

This table reports the results for regressions where workplace injuries and illnesses (TCR) is regressed on CEO power (CEO duality or CEO pay slice) and a set of control variables. TCR is the number of workrelated injury and illness cases divided with the number of hours worked multiplied with 200,000. Our main independent variable is CEO duality in columns (1) to (3) and CEO pay slice in columns (4) to (6). CEO duality is an indicator variable taking the value 1 if the CEO of the firm is also the chairperson of the firm, and 0 otherwise. CEO pay slice is measured as the proportion of the aggregated firm's top-five executive compensation obtained by the CEO. We provide definitions of all control variables in Appendix in Table 10. $t$-statistics are presented in the parentheses and calculated from robust standard errors clustered at the firm-level

Coefficients marked with $* * *$, and $* * *$ are significant at $10 \%, 5 \%$, and $1 \%$ level, respectively 
Table 5 Days away from work and deaths

\begin{tabular}{|c|c|c|c|c|}
\hline & DAW & DAW & DCR & DCR \\
\hline CEO duality & $\begin{array}{l}-39.77 * * * \\
(-4.56)\end{array}$ & & $\begin{array}{l}-0.00 \\
(-1.24)\end{array}$ & \\
\hline CEO pay slice & & $\begin{array}{l}-73.17^{*} \\
(-1.66)\end{array}$ & & $\begin{array}{l}0.00 \\
(0.03)\end{array}$ \\
\hline LnAge & $\begin{array}{l}-205.35^{* * * *} \\
(-4.12)\end{array}$ & $\begin{array}{l}-192.96 * * * \\
(-3.53)\end{array}$ & $\begin{array}{l}0.01 \\
(1.41)\end{array}$ & $\begin{array}{l}0.01 \\
(1.43)\end{array}$ \\
\hline LnTenure & $\begin{array}{l}-8.72 \\
(-1.29)\end{array}$ & $\begin{array}{l}-8.21 \\
(-1.22)\end{array}$ & $\begin{array}{l}-0.00 \\
(-0.46)\end{array}$ & $\begin{array}{l}-0.00 \\
(-0.56)\end{array}$ \\
\hline Female CEO & $\begin{array}{l}-27.06 \\
(-1.62)\end{array}$ & $\begin{array}{l}-32.73^{*} \\
(-1.80)\end{array}$ & $\begin{array}{l}-0.00 \\
(-0.98)\end{array}$ & $\begin{array}{l}-0.00 \\
(-1.10)\end{array}$ \\
\hline $\begin{array}{l}\text { Hours per } \\
\text { employee }\end{array}$ & $\begin{array}{l}-0.12 * * * \\
(-2.97)\end{array}$ & $\begin{array}{l}-0.12 * * * \\
(-2.96)\end{array}$ & $\begin{array}{l}-0.00 \\
(-0.55)\end{array}$ & $\begin{array}{l}-0.00 \\
(-0.56)\end{array}$ \\
\hline $\begin{array}{l}\text { Establishment } \\
\text { size }\end{array}$ & $\begin{array}{l}5.41 * \\
(1.91)\end{array}$ & $\begin{array}{l}5.12 * \\
(1.78)\end{array}$ & $\begin{array}{l}-0.00 * * \\
(-2.43)\end{array}$ & $\begin{array}{l}-0.00 * * \\
(-2.42)\end{array}$ \\
\hline LnAssets & $\begin{array}{l}3.35 \\
(0.68)\end{array}$ & $\begin{array}{l}3.95 \\
(0.77)\end{array}$ & $\begin{array}{l}0.00 \\
(1.10)\end{array}$ & $\begin{array}{l}0.00 \\
(1.14)\end{array}$ \\
\hline Leverage & $\begin{array}{l}14.45 \\
(0.38)\end{array}$ & $\begin{array}{l}16.71 \\
(0.43)\end{array}$ & $\begin{array}{l}-0.00 \\
(-0.03)\end{array}$ & $\begin{array}{l}0.00 \\
(0.08)\end{array}$ \\
\hline PPE/assets & $\begin{array}{l}154.23 * * * \\
(4.38)\end{array}$ & $\begin{array}{l}156.57 * * * \\
(4.30)\end{array}$ & $\begin{array}{l}-0.00 \\
(-0.51)\end{array}$ & $\begin{array}{l}-0.00 \\
(-0.54)\end{array}$ \\
\hline Sales/assets & $\begin{array}{l}-1.81 \\
(-0.14)\end{array}$ & $\begin{array}{l}-6.84 \\
(-0.51)\end{array}$ & $\begin{array}{l}0.00 \\
(1.00)\end{array}$ & $\begin{array}{l}0.00 \\
(0.92)\end{array}$ \\
\hline Capex/assets & $\begin{array}{l}-73.95 \\
(-0.37)\end{array}$ & $\begin{array}{l}-95.23 \\
(-0.44)\end{array}$ & $\begin{array}{l}0.02 \\
(1.03)\end{array}$ & $\begin{array}{l}0.02 \\
(0.99)\end{array}$ \\
\hline Market/book & $\begin{array}{l}-1.12 \\
(-0.15)\end{array}$ & $\begin{array}{l}-1.72 \\
(-0.22)\end{array}$ & $\begin{array}{l}-0.00 \\
(-0.39)\end{array}$ & $\begin{array}{l}-0.00 \\
(-0.41)\end{array}$ \\
\hline Strike & $\begin{array}{l}12.10 \\
(0.28)\end{array}$ & $\begin{array}{l}5.85 \\
(0.13)\end{array}$ & $\begin{array}{l}-0.00 \\
(-0.66)\end{array}$ & $\begin{array}{l}-0.00 \\
(-0.69)\end{array}$ \\
\hline Shutdown & $\begin{array}{l}21.09 * * \\
(2.25)\end{array}$ & $\begin{array}{l}19.49 * * \\
(2.12)\end{array}$ & $\begin{array}{l}-0.00^{*} \\
(-1.85)\end{array}$ & $\begin{array}{l}-0.00^{*} \\
(-1.82)\end{array}$ \\
\hline Seasonal & $\begin{array}{l}7.16 \\
(0.51)\end{array}$ & $\begin{array}{l}1.33 \\
(0.08)\end{array}$ & $\begin{array}{l}-0.00 \\
(-0.01)\end{array}$ & $\begin{array}{l}-0.00 \\
(-0.14)\end{array}$ \\
\hline Disaster & $\begin{array}{l}45.33^{*} \\
(1.66)\end{array}$ & $\begin{array}{l}46.35^{*} \\
(1.72)\end{array}$ & $\begin{array}{l}-0.00 \\
(-0.17)\end{array}$ & $\begin{array}{l}-0.00 \\
(-0.16)\end{array}$ \\
\hline Constant & $\begin{array}{l}1084.16 * * * \\
(5.10)\end{array}$ & $\begin{array}{l}1044.11^{* * *} \\
(4.54)\end{array}$ & $\begin{array}{l}0.00 \\
(0.04)\end{array}$ & $\begin{array}{l}-0.00 \\
(-0.03)\end{array}$ \\
\hline Industry FE & YES & YES & YES & YES \\
\hline Year FE & YES & YES & YES & YES \\
\hline State FE & YES & YES & YES & YES \\
\hline R-squared & 0.239 & 0.236 & 0.004 & 0.004 \\
\hline Level & Est.-year & Est.-year & Est.-year & Est.-year \\
\hline Observations & 31,924 & 31,924 & 31,924 & 31,924 \\
\hline
\end{tabular}

This table reports the results for regressions where either days away from work due to injury (DAW) or workplace injuries and illnesses leading to deaths (DCR) is regressed on CEO power (CEO duality or CEO pay slice) and a set of control variables. DAW is the dependent variable in column (1) and (2), it is calculated as the number of days away from work due to workplace injury and illness cases divided with the number of hours worked multiplied with 200,000 . DCR is the dependent variable in column (3) and (4), it is calculated as the
Table 5 (continued)

number of deaths due to workplace injury and illness cases divided with the number of hours worked multiplied with 200,000. Our main independent variable is CEO duality in column (1) and (2) and CEO pay slice in column (3) and (4). CEO duality is an indicator variable taking the value 1 if the $\mathrm{CEO}$ of the firm is also the chairperson of the firm, and 0 otherwise. CEO pay slice is measured as the proportion of the aggregated firm's top-five executive compensation obtained by the CEO. We provide definitions of all control variables in Appendix in Table 10. $t$-statistics are presented in the parentheses and calculated from robust standard errors clustered at the firm-level

Coefficients marked with $*, * *$, and $* * *$ are significant at $10 \%, 5 \%$, and $1 \%$ level, respectively

within their firms. We determine a firm's location based on the corporate headquarters information in the Compustat database. For the aforementioned states, we code an indicator variable NonCompChange with +1 in the years following the change, and 0 for the years prior to it. During our sample period, there were also three states that weakened the enforceability of non-compete agreements: Louisiana (2001), Oregon (2008), and South Carolina (2010). For firms in these states, we code NonCompChange with -1 for the years following the change, and 0 for the years prior to it. We expect the CEOs of firms located in these states to experience a negative power shock, which in turn should increase workplace injuries and illnesses within their firms. We code NonCompChange with 0 for all the other states.

Table 6 reports the regression results where we replace the structural CEO power measures with NonCompChange. For both injuries and illnesses and days away from work, the significantly negative coefficient on NonCompChange indicates that safety and health records improve when CEO power increases. ${ }^{10}$ Thus, exploiting this legal shock to CEO power, our evidence suggests that more CEO power have a positive effect on workplace safety and health. As before, the result for DCR is insignificant.

\section{Additional Results}

In additional analyses, we further explore the relationship between CEO power and workplace injuries and illnesses. We examine whether the three other CEO power dimensions of Finkelstein (1992) have a similar relationship with workplace safety and health as structural power. Moreover, we study how the relationship between CEO power and workplace injuries and illnesses are affected by proximity

\footnotetext{
10 The $t$-statistics in Table 6 are calculated based on robust and clustered standard errors on the state-level. We cluster on state-level because our main independent variable is measured on the state-level in this test.
} 
Table 6 Identification test

\begin{tabular}{|c|c|c|c|}
\hline & TCR & DAW & DCR \\
\hline NonCompChange & $\begin{array}{l}-0.877 * * \\
(-2.65)\end{array}$ & $\begin{array}{l}-16.735^{* *} \\
(-2.21)\end{array}$ & $\begin{array}{l}0.000 \\
(0.04)\end{array}$ \\
\hline LnAge & $\begin{array}{l}-5.494 * * * \\
(-7.00)\end{array}$ & $\begin{array}{l}-191.220 * * * \\
(-8.60)\end{array}$ & $\begin{array}{l}0.008 * * \\
(2.11)\end{array}$ \\
\hline LnTenure & $\begin{array}{l}0.040 \\
(0.44)\end{array}$ & $\begin{array}{l}-11.915 * * * \\
(-4.75)\end{array}$ & $\begin{array}{l}-0.000 \\
(-0.45)\end{array}$ \\
\hline Female CEO & $\begin{array}{l}-0.632 \\
(-1.42)\end{array}$ & $\begin{array}{l}-35.022 * * \\
(-2.37)\end{array}$ & $\begin{array}{l}-0.002 \\
(-0.76)\end{array}$ \\
\hline Hours per employee & $\begin{array}{l}-0.004 * * * \\
(-15.67)\end{array}$ & $\begin{array}{l}-0.117 * * * \\
(-11.80)\end{array}$ & $\begin{array}{l}-0.000 \\
(-0.68)\end{array}$ \\
\hline Establishment size & $\begin{array}{l}0.067 \\
(0.97)\end{array}$ & $\begin{array}{l}4.925^{*} \\
(1.83)\end{array}$ & $\begin{array}{l}-0.002^{* *} \\
(-2.20)\end{array}$ \\
\hline LnAssets & $\begin{array}{l}-0.132 * \\
(-1.84)\end{array}$ & $\begin{array}{l}4.211 * * \\
(2.07)\end{array}$ & $\begin{array}{l}0.001 \\
(1.32)\end{array}$ \\
\hline Leverage & $\begin{array}{l}4.239 * * * \\
(6.27)\end{array}$ & $\begin{array}{l}30.566^{*} \\
(1.71)\end{array}$ & $\begin{array}{l}0.000 \\
(0.09)\end{array}$ \\
\hline PPE/assets & $\begin{array}{l}0.401 \\
(0.61)\end{array}$ & $\begin{array}{l}156.708^{* * * *} \\
(7.62)\end{array}$ & $\begin{array}{l}-0.002 \\
(-0.46)\end{array}$ \\
\hline Sales/assets & $\begin{array}{l}-0.145 \\
(-1.10)\end{array}$ & $\begin{array}{l}-5.608 \\
(-1.16)\end{array}$ & $\begin{array}{l}0.001 \\
(0.99)\end{array}$ \\
\hline Capex/assets & $\begin{array}{l}6.503 * * \\
(2.24)\end{array}$ & $\begin{array}{l}-119.748 * \\
(-1.79)\end{array}$ & $\begin{array}{l}0.018 \\
(0.84)\end{array}$ \\
\hline Market/book & $\begin{array}{l}-0.026 \\
(-0.23)\end{array}$ & $\begin{array}{l}-1.652 \\
(-0.46)\end{array}$ & $\begin{array}{l}-0.000 \\
(-0.48)\end{array}$ \\
\hline Strike & $\begin{array}{l}1.009 \\
(0.79)\end{array}$ & $\begin{array}{l}9.098 \\
(0.17)\end{array}$ & $\begin{array}{l}-0.001 \\
(-0.68)\end{array}$ \\
\hline Shutdown & $\begin{array}{l}0.604 * * \\
(2.44)\end{array}$ & $\begin{array}{l}19.302 * * * \\
(2.80)\end{array}$ & $\begin{array}{l}-0.002 * \\
(-1.76)\end{array}$ \\
\hline Seasonal & $\begin{array}{l}-0.308 \\
(-0.59)\end{array}$ & $\begin{array}{l}0.492 \\
(0.03)\end{array}$ & $\begin{array}{l}-0.000 \\
(-0.20)\end{array}$ \\
\hline Disaster & $\begin{array}{l}1.373^{*} \\
(1.91)\end{array}$ & $\begin{array}{l}46.625 \\
(1.55)\end{array}$ & $\begin{array}{l}-0.001 \\
(-0.20)\end{array}$ \\
\hline Constant & $\begin{array}{l}37.905 * * * \\
(10.75)\end{array}$ & $\begin{array}{l}1009.629 * * * \\
(9.62)\end{array}$ & $\begin{array}{l}-0.001 \\
(-0.03)\end{array}$ \\
\hline Industry FE & YES & YES & YES \\
\hline Year FE & YES & YES & YES \\
\hline State FE & YES & YES & YES \\
\hline R-squared & 0.301 & 0.236 & 0.004 \\
\hline Level & Est.-year & Est.-year & Est.-year \\
\hline Observations & 31,924 & 31,924 & 31,924 \\
\hline
\end{tabular}

This table reports the results for regressions where workplace injuries and illnesses (TCR) is regressed on NonCompChange and a set of control variables. TCR is the number of work-related injury and illness cases divided with the number of hours worked multiplied with 200,000. Our main independent variable NonCompChange is an indicator variable, taking the value $1(-1)$ if the establishment state had an increase (decrease) in non-compete enforceability and 0 otherwise. We provide definitions of all control variables in Appendix in Table 10. $t$-statistics are presented in the parentheses and calculated from robust standard errors clustered at the state-level

Coefficients marked with $*, * *$, and $* * *$ are significant at $10 \%, 5 \%$, and $1 \%$ level, respectively of the establishment to corporate headquarters, compensation incentives, and corporate governance.

\section{Other Dimensions of CEO Power}

Our main analyses focus on the structural dimension of power. However, according to Finkelstein (1992), power also arises from ownership, expertise, and prestige. In Table 7 , we study the association between these three additional power dimensions and workplace injuries and illnesses. To examine the impact from ownership power, we follow Adams et al. (2005) and compare the rates of injuries and illnesses at firms where the CEO is the founder of the firm with firms where the CEO is not (Founder). We obtain the dataset on founder CEOs from Lee et al. (2017). Since that dataset does not cover all our firm-year observations, we obtain founder data for the missing observations by manual collection using the Google search engine. Regarding expertise power, Li et al. (2014) argue that communication patterns during conference calls indicate the relative knowledge dispersion within the management team. Thus, we proxy CEO expertise power with their measure (Percentage CEO text). The measure is calculated by dividing the number of characters spoken by the CEO during conference calls by the number of characters spoken by all executives during conference calls. The third additional dimension of power is prestige, and Finkelstein (1992) suggests that a source of prestige power is an elite education. Thus, we follow the approach applied by El-Khatib et al. (2015) and proxy prestige power with a variable indicating whether the CEO attended an Ivy League school (Ivy League). We used the Google search engine to manually collect data on CEO education.

Column (1) and (2) of Table 7 show the results for Eq. (1) when we use Founder as a measure of CEO power. The results suggest that firms governed by a founder have a higher rate of workplace injuries and illnesses. In Column (2), the coefficient for Founder is 2.63 ( $t$-stat 2.47). On a yearly basis, this suggests that firms with founder CEOs have 2.63 more injuries and illnesses per 100 full time employees. These results are opposite to our main results. However, they are reasonable because founder CEOs, from a utility maximization perspective, have less desire to pursue private benefits at the expense of the shareholders. In Column (3) and (4), we examine whether CEO power through expertise is related to workplace injuries and illnesses. While the number of observations is lower in these columns because the expertise power measure is not available for all observations, the coefficient for Percentage CEO text is negative and significant. Thus, structural and expertise power have a similar relationship with workplace injuries and illnesses. Finally, the last two columns of Table 7 show that the relationship between prestige power and workplace injuries and illnesses is statistically insignificant. Taken together, these 
Table 7 Other dimensions of CEO power

\begin{tabular}{|c|c|c|c|c|c|c|}
\hline & TCR & TCR & TCR & TCR & TCR & TCR \\
\hline Founder & $\begin{array}{l}1.80^{* *} \\
(2.14)\end{array}$ & $\begin{array}{l}2.63 * * \\
(2.47)\end{array}$ & & & & \\
\hline Percentage CEO text & & & $\begin{array}{l}-0.04 * * * \\
(-2.77)\end{array}$ & $\begin{array}{l}-0.04 * * * \\
(-3.86)\end{array}$ & & \\
\hline Ivy League & & & & & $\begin{array}{l}0.05 \\
(0.06)\end{array}$ & $\begin{array}{l}-0.03 \\
(-0.07)\end{array}$ \\
\hline LnAge & & $\begin{array}{l}-5.49 * * * \\
(-3.94)\end{array}$ & & $\begin{array}{l}-3.59 \\
(-1.16)\end{array}$ & & $\begin{array}{l}-5.42 * * * \\
(-3.78)\end{array}$ \\
\hline LnTenure & & $\begin{array}{l}-0.04 \\
(-0.18)\end{array}$ & & $\begin{array}{l}-0.13 \\
(-0.55)\end{array}$ & & $\begin{array}{l}0.04 \\
(0.19)\end{array}$ \\
\hline Female CEO & & $\begin{array}{l}-0.56 \\
(-0.80)\end{array}$ & & $\begin{array}{l}-0.60 \\
(-0.60)\end{array}$ & & $\begin{array}{l}-0.61 \\
(-0.87)\end{array}$ \\
\hline Hours per employee & & $\begin{array}{l}-0.00 * * * \\
(-3.87)\end{array}$ & & $\begin{array}{l}-0.00^{* * *} \\
(-3.50)\end{array}$ & & $\begin{array}{l}-0.00 * * * \\
(-3.81)\end{array}$ \\
\hline Establishment size & & $\begin{array}{l}0.08 \\
(0.54)\end{array}$ & & $\begin{array}{l}0.02 \\
(0.18)\end{array}$ & & $\begin{array}{l}0.07 \\
(0.49)\end{array}$ \\
\hline LnAssets & & $\begin{array}{l}-0.11 \\
(-0.43)\end{array}$ & & $\begin{array}{l}-0.65^{* * *} \\
(-3.57)\end{array}$ & & $\begin{array}{l}-0.11 \\
(-0.46)\end{array}$ \\
\hline Leverage & & $\begin{array}{l}4.42 * * \\
(2.08)\end{array}$ & & $\begin{array}{l}5.15^{*} \\
(1.75)\end{array}$ & & $\begin{array}{l}4.28^{*} \\
(1.86)\end{array}$ \\
\hline PPE/assets & & $\begin{array}{l}0.26 \\
(0.16)\end{array}$ & & $\begin{array}{l}-6.57^{* * *} \\
(-2.89)\end{array}$ & & $\begin{array}{l}0.17 \\
(0.10)\end{array}$ \\
\hline Sales/assets & & $\begin{array}{l}-0.26 \\
(-0.59)\end{array}$ & & $\begin{array}{l}-0.10 \\
(-0.19)\end{array}$ & & $\begin{array}{l}-0.20 \\
(-0.42)\end{array}$ \\
\hline Capex/assets & & $\begin{array}{l}6.52 \\
(0.54)\end{array}$ & & $\begin{array}{l}22.57 * \\
(1.68)\end{array}$ & & $\begin{array}{l}7.05 \\
(0.62)\end{array}$ \\
\hline Market/book & & $\begin{array}{l}-0.00 \\
(-0.01)\end{array}$ & & $\begin{array}{l}-0.13 \\
(-0.37)\end{array}$ & & $\begin{array}{l}-0.03 \\
(-0.11)\end{array}$ \\
\hline Strike & & $\begin{array}{l}0.99 \\
(0.78)\end{array}$ & & $\begin{array}{l}1.62 \\
(0.82)\end{array}$ & & $\begin{array}{l}1.03 \\
(0.82)\end{array}$ \\
\hline Shutdown & & $\begin{array}{l}0.62 * \\
(1.76)\end{array}$ & & $\begin{array}{l}0.75 \\
(1.32)\end{array}$ & & $\begin{array}{l}0.60 * \\
(1.72)\end{array}$ \\
\hline Seasonal & & $\begin{array}{l}-0.38 \\
(-0.43)\end{array}$ & & $\begin{array}{l}1.71^{* * * *} \\
(3.96)\end{array}$ & & $\begin{array}{l}-0.34 \\
(-0.38)\end{array}$ \\
\hline Disaster & & $\begin{array}{l}1.31 * \\
(1.74)\end{array}$ & & $\begin{array}{l}0.78 \\
(0.96)\end{array}$ & & $\begin{array}{l}1.38^{*} \\
(1.81)\end{array}$ \\
\hline Constant & $\begin{array}{l}6.46^{* * * *} \\
(4.20)\end{array}$ & $\begin{array}{l}37.05^{* * * *} \\
(6.90)\end{array}$ & $\begin{array}{l}6.21 * * * \\
(3.46)\end{array}$ & $\begin{array}{l}37.87 \text { *** } \\
(2.89)\end{array}$ & $\begin{array}{l}7.08 * * * \\
(3.92)\end{array}$ & $\begin{array}{l}37.63^{* * *} \\
(6.44)\end{array}$ \\
\hline Industry FE & YES & YES & YES & YES & YES & YES \\
\hline Year FE & YES & YES & YES & YES & YES & YES \\
\hline State FE & YES & YES & YES & YES & YES & YES \\
\hline R-squared & 0.259 & 0.303 & 0.270 & 0.325 & 0.258 & 0.300 \\
\hline Level & Est.-year & Est.-year & Est.-year & Est.-yyear & Est.-year & Est.-year \\
\hline Observations & 31,924 & 31,924 & 13,002 & 13,002 & 31,924 & 31,924 \\
\hline
\end{tabular}

This table reports the results for regressions where workplace injuries and illnesses (TCR) is regressed on alternative CEO power dimensions (Founder, Percentage CEO speak, or Ivy League) and a set of control variables. TCR is the number of work-related injury and illness cases divided with the number of hours worked multiplied with 200,000. Founder is an indicator variable taking the value 1 if the CEO of the firm is also the founder or one of the founders, and 0 otherwise. CEO pay slice is measured as the proportion of the aggregated firm's top-five executive compensation obtained by the CEO. Ivy League is an indicator variable taking the value 1 if the $\mathrm{CEO}$ of the firm has received a degree from one of the Ivy League universities, and 0 otherwise. We provide definitions of all control variables in Appendix in Table 10. $t$-statistics are presented in the parentheses and calculated from robust standard errors clustered at the firm-level Coefficients marked with $* * *$, and $* * *$ are significant at $10 \%, 5 \%$, and $1 \%$ level, respectively 
results highlight that the relationship between CEO power and workplace injuries and illnesses depends on the power dimension.

\section{Proximity to Corporate Headquarters}

Landier et al. (2009) provide evidence that CEOs show favoritism towards employees geographically closer to the corporate headquarters as these employees are less likely to be laid off. Similarly, Cronqvist et al. (2009) find higher wages for employees who are positioned closer to the corporate headquarters if the CEO is entrenched. In Table 8, we examine whether rates of injuries and illnesses vary by establishment location and whether the variation depends on if the firm is governed by a structurally powerful CEO. We especially compare the injury and illness rates between establishments in the same state as the corporate headquarters and establishments in other states (Different state).

In Column (1) and (2) of Table 8, we examine whether establishments in other states than the corporate headquarters have higher TCR. Different state is an indicator variable, taking the value 1 if the establishment is not located in the same state as the headquarters, and 0 otherwise. In Column (1), we report the results for TCR as the dependent variable and Different state, firm controls, establishment controls, and Year fixed-effects as independent variables. The coefficient for Different state is positive and significant (coeff. $0.77, t$-stat 2.16), suggesting that establishments in a different state than the corporate headquarters have higher injury and illness rates. In Column (2), we add fixed-effects from Industry and State. In this specification the coefficient for Different state is positive and insignificant. Taken together, the columns suggest that establishments not located in the same state as the corporate headquarters have higher injury and illness rates, but that the difference is at least partially explained by different types of industries. We reason that establishments located farther away from the corporate headquarters belong to more hazardous industries. In Column (3) and (4) of Table 8, we study whether structurally powerful CEOs affect differences in injury and illness rates related to proximity to corporate headquarters. In Column (3), the coefficient for the interaction term (CEO duality*Different state) is negative and statistically significant. In economic terms, the coefficient of $-0.51(t$-stat -1.67$)$ indicates that structurally powerful CEOs have 0.51 fewer injuries and illnesses per 100 full time employees in establishments positioned outside the corporate headquarters state. The result in Column (4) of Table 8 also suggests that structurally more powerful CEOs mitigate differences in the rates of workplace injury and illness between headquarters state establishments and those outside the state in which the headquarters are located.

\section{CEO Compensation Contracts}

In Table 9, we test whether compensation contracts incentivizing lower workplace injuries and illnesses are associated with lower rates of injuries and illnesses and whether structurally powerful CEOs are more likely to have such compensation contracts. In Panel A of Table 9, TCR is the dependent variable and safety and health incentives (Incentive) our independent variable of interest. Column (1) shows a negative association between the two variables and Column (2) shows that the negative association between Incentive and TCR is also statistically significant after including control variables. The coefficient of -1.31 is also economically significant, suggesting that there are 1.31 fewer injuries and illnesses per 100 full-time employees for firm-years when the CEO compensation is tied to workplace injuries and illnesses. These results for establishment-year observations also remains for firm-year observations (Column 3). In Column (4) and (5) of Panel A, we also include CEO power in the regression. The results show that CEO power is negatively associated with TCR also when Incentive is controlled for.

In Panel B of Table 9, we examine whether structurally powerful CEOs are more likely to have compensation contracts incentivizing lower workplace injuries and illnesses. Abernethy et al. (2015) suggest that powerful CEOs are to some extent able to influence the design of their compensation. If powerful CEOs prefer lower injury and illness rates, they may encourage such metrics in the compensation system. To examine this, we estimate linear probability models with Incentive as the dependent variable and one of the two structural CEO power measures as main independent variable. We find that the association between our power measures and safety and health incentives are positive, however, statistically insignificant. In summary, the results in Table 9 show that safety and health incentives reduce workplace injuries and illnesses, however the reason for why structurally powerful CEOs have fewer workplace injuries and illnesses are not solely due to more safety and health incentives in their compensation packages.

\section{Corporate Governance}

High quality corporate governance could constrain a powerful CEO from behaving opportunistically, or as proposed in this study it could limit the ability of the CEO to harvest private benefits. To ensure that our association between structural CEO power and workplace injuries and illnesses 
Table 8 Proximity to corporate headquarters

\begin{tabular}{|c|c|c|c|c|}
\hline & TCR & TCR & TCR & TCR \\
\hline Different state & $\begin{array}{l}0.77 * * \\
(2.16)\end{array}$ & $\begin{array}{l}0.33 \\
(1.04)\end{array}$ & $\begin{array}{l}0.58^{*} \\
(1.93)\end{array}$ & $\begin{array}{l}2.47 * * * \\
(3.59)\end{array}$ \\
\hline CEO duality & & & $\begin{array}{l}-1.31^{* * * *} \\
(-3.27)\end{array}$ & \\
\hline CEO duality $\times$ Different state & & & $\begin{array}{l}-0.51^{*} \\
(-1.67)\end{array}$ & \\
\hline CEO pay slice & & & & $\begin{array}{l}0.37 \\
(0.16)\end{array}$ \\
\hline CEO pay slice $\times$ Different state & & & & $\begin{array}{l}-5.03 * * * \\
(-3.07)\end{array}$ \\
\hline LnAge & & & $\begin{array}{l}-6.20^{* * *} \\
(-4.48)\end{array}$ & $\begin{array}{l}-5.70^{* * *} \\
(-4.04)\end{array}$ \\
\hline LnTenure & & & $\begin{array}{l}0.19 \\
(1.03)\end{array}$ & $\begin{array}{l}0.26 \\
(0.98)\end{array}$ \\
\hline Female CEO & & & $\begin{array}{l}-0.29 \\
(-0.46)\end{array}$ & $\begin{array}{l}-0.49 \\
(-0.65)\end{array}$ \\
\hline Hours per employee & $\begin{array}{l}-0.01 * * * \\
(-3.17)\end{array}$ & $\begin{array}{l}-0.00 * * * \\
(-4.12)\end{array}$ & $\begin{array}{l}-0.00^{* * *} \\
(-3.89)\end{array}$ & $\begin{array}{l}-0.00 * * * \\
(-3.87)\end{array}$ \\
\hline Establishment size & $\begin{array}{l}-0.11 \\
(-0.57)\end{array}$ & $\begin{array}{l}0.10 \\
(0.69)\end{array}$ & $\begin{array}{l}0.10 \\
(0.74)\end{array}$ & $\begin{array}{l}0.09 \\
(0.66)\end{array}$ \\
\hline LnAssets & $\begin{array}{l}0.04 \\
(0.17)\end{array}$ & $\begin{array}{l}-0.13 \\
(-0.52)\end{array}$ & $\begin{array}{l}-0.17 \\
(-0.68)\end{array}$ & $\begin{array}{l}-0.15 \\
(-0.58)\end{array}$ \\
\hline Leverage & $\begin{array}{l}7.52 * * \\
(2.23)\end{array}$ & $\begin{array}{l}4.61 * * \\
(2.24)\end{array}$ & $\begin{array}{l}3.51 \% \\
(1.77)\end{array}$ & $\begin{array}{l}3.44 * \\
(1.72)\end{array}$ \\
\hline PPE/assets & $\begin{array}{l}1.48 \\
(0.95)\end{array}$ & $\begin{array}{l}-0.19 \\
(-0.11)\end{array}$ & $\begin{array}{l}0.22 \\
(0.14)\end{array}$ & $\begin{array}{l}0.33 \\
(0.21)\end{array}$ \\
\hline Sales/assets & $\begin{array}{l}0.17 \\
(0.34)\end{array}$ & $\begin{array}{l}-0.40 \\
(-0.83)\end{array}$ & $\begin{array}{l}0.02 \\
(0.05)\end{array}$ & $\begin{array}{l}-0.20 \\
(-0.42)\end{array}$ \\
\hline Capex/assets & $\begin{array}{l}13.58 \\
(1.09)\end{array}$ & $\begin{array}{l}12.22 \\
(0.91)\end{array}$ & $\begin{array}{l}8.92 \\
(0.84)\end{array}$ & $\begin{array}{l}8.37 \\
(0.75)\end{array}$ \\
\hline Market/book & $\begin{array}{l}0.76 \\
(1.25)\end{array}$ & $\begin{array}{l}-0.13 \\
(-0.48)\end{array}$ & $\begin{array}{l}-0.01 \\
(-0.03)\end{array}$ & $\begin{array}{l}-0.03 \\
(-0.12)\end{array}$ \\
\hline Strike & $\begin{array}{l}1.95 \\
(1.30)\end{array}$ & $\begin{array}{l}1.19 \\
(0.94)\end{array}$ & $\begin{array}{l}1.17 \\
(0.94)\end{array}$ & $\begin{array}{l}1.03 \\
(0.82)\end{array}$ \\
\hline Shutdown & $\begin{array}{l}0.25 \\
(0.41)\end{array}$ & $\begin{array}{l}0.60^{*} \\
(1.74)\end{array}$ & $\begin{array}{l}0.68^{*} \\
(1.93)\end{array}$ & $\begin{array}{l}0.62 * \\
(1.80)\end{array}$ \\
\hline Seasonal & $\begin{array}{l}-0.81 \\
(-0.75)\end{array}$ & $\begin{array}{l}-0.33 \\
(-0.39)\end{array}$ & $\begin{array}{l}-0.04 \\
(-0.05)\end{array}$ & $\begin{array}{l}-0.28 \\
(-0.33)\end{array}$ \\
\hline Disaster & $\begin{array}{l}1.51 \\
(1.49)\end{array}$ & $\begin{array}{l}1.61 * * \\
(1.97)\end{array}$ & $\begin{array}{l}1.36^{*} \\
(1.81)\end{array}$ & $\begin{array}{l}1.37 * \\
(1.84)\end{array}$ \\
\hline Constant & $\begin{array}{l}14.28 * * * \\
(3.47)\end{array}$ & $\begin{array}{l}16.45^{* * *} \\
(3.61)\end{array}$ & $\begin{array}{l}41.09 * * * \\
(6.98)\end{array}$ & $\begin{array}{l}38.00 * * * \\
(6.38)\end{array}$ \\
\hline Industry FE & NO & YES & YES & YES \\
\hline Year FE & YES & YES & YES & YES \\
\hline State FE & NO & YES & YES & YES \\
\hline R-squared & 0.175 & 0.296 & 0.310 & 0.305 \\
\hline Level & Est.-year & Est.-year & Est.-year & Est.-year \\
\hline Observations & 31,924 & 31,924 & 31,924 & 31,924 \\
\hline
\end{tabular}

This table reports the results for regressions where workplace injuries and illnesses (TCR) is regressed on an interaction between Different state and CEO power (CEO duality or CEO pay slice) and a set of control variables. TCR is the number of work-related injury and illness cases divided with the number of hours worked multiplied with 200,000. Different state is an indicator variable taking the value 1 if the establishment is located in a different state than the corporate headquarters of the firm, and 0 otherwise. CEO duality is an indicator variable taking the value 1 if the CEO of the firm is also the chairperson of the firm, and 0 otherwise. CEO pay slice is measured as the proportion of the aggregated firm's top-five executive com- 
Table 8 (continued)

pensation obtained by the CEO. We provide definitions of all control variables in Appendix in Table 10. $t$-statistics are presented in the parentheses and calculated from robust standard errors clustered at the firmlevel

Coefficients marked with *,**, and $* * *$ are significant at $10 \%, 5 \%$, and $1 \%$ level, respectively

is robust we include additional control variables for institutional ownership and corporate governance. ${ }^{11}$ For institutional ownership, we include the fraction owned by the 10 largest institutional owners. Chung and Zhang (2011) show that larger institutional ownership is associated with better corporate governance. We also include a corporate governance index, calculated using KLD Research and Analytics by taking the number of strengths minus the number of weaknesses from within the category corporate governance. Because these variables are not available for our full sample, we do not tabulate the results. Nonetheless, we find that the previously significant negative association between structural CEO power and workplace injuries and illnesses is unaffected by the inclusion of the additional controls.

\section{Conclusions}

Given the considerable economic and social costs associated with workplace injuries and illnesses, it is important to understand the underlying causes. This study explores the effects of CEO power. Our findings show that workplace injuries and illnesses and days away from work are decreasing with a structurally powerful CEO in charge. However, an association between CEO power and employee deaths was not found. The takeaway of our study is consistent with the study of Cronqvist et al. (2009), which claims that CEOs with more control pay their employees more to obtain private benefits.

In contrast to the contemporary view that powerful CEOs are ruthless exploiters (Amernic and Craig 2017; Wong 2018; Eidelson and Hull 2019; Evans 2019; Ohnsman 2019; Sainato 2020), we find, on average, that powerful CEOs are ethical guardians of the workforce. Our study suggests that powerful CEOs are better positioned to foster safe workplaces, and we thus inform practice of the bright side of powerful leaders. By so doing, our study could provide insight for safety and health committees and unions. Stakeholders concerned about occupational safety and health should pay attention to the characteristics of management because they influence workplace injuries and illnesses. Without the support and power of top executives in firms, the efforts of concerned stakeholders may not translate into concrete actions. The results are also generally informative for shareholders seeking sustainable investments.

\footnotetext{
11 These two variables are not included in our main regressions because the associated data restrictions significantly reduce our sample.
}

Overall, we contribute to the literature on workplace safety and health, CEO power, and CSR. Prior studies on the driving and moderating factors of workplace injuries and illnesses have primarily focused on organizational factors such as financial constraints (Cohn and Wardlaw 2016; Bradley et al. 2018) and capital market factors such as pressure (Caskey and Ozel 2017; Christensen et al. 2017; Bradley et al. 2019). We contribute by focusing on a void in the literature, being the key role of powerful top executives. This research is timely given the recent media attention on the topic and considering that prior workplace safety and health studies including CEOs are limited and focused on matters other than power. Furthermore, we contribute to the CEO power literature where several studies document negative consequences of power such as manipulation of incentive contracts (Morse et al. 2011) and power abuse (Yuan et al. 2020). Our finding that powerful CEOs moderated the frequency of injuries and illnesses represents a more positive view of power, especially from the perspective of employees. As such, our evidence is supportive of the effects of powerful CEOs documented by Walls and Berrone (2017) and enriches the ethics literature focusing on the bright side of power. More broadly, we also contribute to the CSR and ethics literature on leadership characteristics where prior studies mainly use aggregate measures of CSR engagement such as EIRIS and KLD ratings (e.g., Fabrizi et al. 2014; Jizi et al. 2014). Fabrizi et al. (2014) incorporate safety and health systems in the aggregate measurement of employee CSR and find a positive link with CEO power. Jizi et al. (2014) also find a positive link between CSR disclosure and CEO duality, however, in contrast to us, they are unable to determine whether stakeholders benefit from powerful CEOs. We extend these studies by using a direct measure of CSR performance. Thus, we provide a more nuanced view of the real CSR effects of CEO power manifested as actual safety and health outcomes.

Our study is subject to limitations that offers directions for future research. One limitation is that we are not able to provide causal evidence. However, in an attempt to more precisely identify the connection between CEO power and workplace injuries and illnesses, we analyze a situation in which we can determine that CEO power increases following exogenous changes in governing laws. While the result of this analysis is consistent with our initial result, future research could find new ways to address the issue. Another limitation is that we rely on the integrity of the OSHA data in our study. Considering the literature on underreporting of workplace injuries and illnesses (Wokutch 1990; Rosenman et al. 2006; Boden and Ozonoff 2008; Petitta et al. 2017), an alternative explanation for our findings, that 
Table 9 CEO compensation contracts

\begin{tabular}{|c|c|c|c|c|c|}
\hline & TCR & TCR & TCR & TCR & TCR \\
\hline \multicolumn{6}{|c|}{$\begin{array}{l}\text { Panel A: safety and health incentives and } \\
\text { injuries and illnesses }\end{array}$} \\
\hline Incentive & $\begin{array}{l}-1.04 * * \\
(-2.41)\end{array}$ & $\begin{array}{l}-1.31 * * * \\
(-3.74)\end{array}$ & $\begin{array}{l}-1.15^{* * *} \\
(-2.69)\end{array}$ & $\begin{array}{l}-0.77 * \\
(-1.93)\end{array}$ & $\begin{array}{l}-1.34 * * * \\
(-3.77)\end{array}$ \\
\hline CEO duality & & & & $\begin{array}{l}-1.72 * * * \\
(-4.24)\end{array}$ & \\
\hline CEO pay slice & & & & & $\begin{array}{l}-4.05^{*} \\
(-1.70)\end{array}$ \\
\hline LnAge & & $\begin{array}{l}-5.50 * * * \\
(-3.92)\end{array}$ & $\begin{array}{l}-1.91 \\
(-1.13)\end{array}$ & $\begin{array}{l}-6.13 * * * \\
(-4.39)\end{array}$ & $\begin{array}{l}-5.66 * * * \\
(-3.96)\end{array}$ \\
\hline LnTenure & & $\begin{array}{l}0.03 \\
(0.15)\end{array}$ & $\begin{array}{l}-0.17 \\
(-0.96)\end{array}$ & $\begin{array}{l}0.17 \\
(0.93)\end{array}$ & $\begin{array}{l}0.24 \\
(0.88)\end{array}$ \\
\hline Female CEO & & $\begin{array}{l}-0.61 \\
(-0.87)\end{array}$ & $\begin{array}{l}-1.34 \\
(-1.19)\end{array}$ & $\begin{array}{l}-0.28 \\
(-0.45)\end{array}$ & $\begin{array}{l}-0.51 \\
(-0.69)\end{array}$ \\
\hline Hours per employee & & $\begin{array}{l}-0.00 * * * \\
(-3.83)\end{array}$ & $\begin{array}{l}-0.00 * * * \\
(-2.78)\end{array}$ & $\begin{array}{l}-0.00 * * * \\
(-3.88)\end{array}$ & $\begin{array}{l}-0.00 * * * \\
(-3.86)\end{array}$ \\
\hline Establishment size & & $\begin{array}{l}0.07 \\
(0.51)\end{array}$ & & $\begin{array}{l}0.09 \\
(0.65)\end{array}$ & $\begin{array}{l}0.08 \\
(0.57)\end{array}$ \\
\hline LnAssets & & $\begin{array}{l}-0.12 \\
(-0.47)\end{array}$ & $\begin{array}{l}-0.16 \\
(-0.54)\end{array}$ & $\begin{array}{l}-0.17 \\
(-0.66)\end{array}$ & $\begin{array}{l}-0.15 \\
(-0.55)\end{array}$ \\
\hline Leverage & & $\begin{array}{l}4.23 * \\
(1.96)\end{array}$ & $\begin{array}{l}1.00 \\
(0.59)\end{array}$ & $\begin{array}{l}3.53^{*} \\
(1.80)\end{array}$ & $\begin{array}{l}3.46^{*} \\
(1.73)\end{array}$ \\
\hline PPE/assets & & $\begin{array}{l}0.24 \\
(0.14)\end{array}$ & $\begin{array}{l}-3.11 * \\
(-1.97)\end{array}$ & $\begin{array}{l}0.29 \\
(0.19)\end{array}$ & $\begin{array}{l}0.46 \\
(0.30)\end{array}$ \\
\hline Sales/assets & & $\begin{array}{l}-0.18 \\
(-0.39)\end{array}$ & $\begin{array}{l}0.96^{* *} \\
(2.49)\end{array}$ & $\begin{array}{l}0.02 \\
(0.04)\end{array}$ & $\begin{array}{l}-0.19 \\
(-0.41)\end{array}$ \\
\hline Capex/assets & & $\begin{array}{l}7.17 \\
(0.59)\end{array}$ & $\begin{array}{l}-1.85 \\
(-0.37)\end{array}$ & $\begin{array}{l}8.60 \\
(0.81)\end{array}$ & $\begin{array}{l}7.81 \\
(0.69)\end{array}$ \\
\hline Market/book & & $\begin{array}{l}-0.03 \\
(-0.13)\end{array}$ & $\begin{array}{l}-0.66^{* * *} \\
(-3.25)\end{array}$ & $\begin{array}{l}-0.01 \\
(-0.03)\end{array}$ & $\begin{array}{l}-0.04 \\
(-0.13)\end{array}$ \\
\hline Strike & & $\begin{array}{l}1.02 \\
(0.80)\end{array}$ & & $\begin{array}{l}1.14 \\
(0.92)\end{array}$ & $\begin{array}{l}0.82 \\
(0.63)\end{array}$ \\
\hline Shutdown & & $\begin{array}{l}0.63^{*} \\
(1.79)\end{array}$ & & $\begin{array}{l}0.70 * * \\
(1.98)\end{array}$ & $\begin{array}{l}0.64 * \\
(1.87)\end{array}$ \\
\hline Seasonal & & $\begin{array}{l}-0.33 \\
(-0.36)\end{array}$ & & $\begin{array}{l}-0.02 \\
(-0.02)\end{array}$ & $\begin{array}{l}-0.25 \\
(-0.29)\end{array}$ \\
\hline Disaster & & $\begin{array}{l}1.35 * \\
(1.79)\end{array}$ & & $\begin{array}{l}1.30^{*} \\
(1.76)\end{array}$ & $\begin{array}{l}1.33^{*} \\
(1.79)\end{array}$ \\
\hline Constant & $\begin{array}{l}7.17 * * * \\
(4.05)\end{array}$ & $\begin{array}{l}38.03 * * * \\
(6.74)\end{array}$ & $\begin{array}{l}19.40 * * * \\
(3.05)\end{array}$ & $\begin{array}{l}41.29 * * * \\
(7.05)\end{array}$ & $\begin{array}{l}40.16^{* * * *} \\
(6.74)\end{array}$ \\
\hline Industry FE & YES & YES & YES & YES & YES \\
\hline Year FE & YES & YES & YES & YES & YES \\
\hline State FE & YES & YES & $\mathrm{NO}$ & YES & YES \\
\hline R-squared & 0.258 & 0.301 & 0.418 & 0.310 & 0.304 \\
\hline Level & Est.-year & Est.-year & Firm-year & Est.-year & Est.-year \\
\hline Observations & 31,924 & 31,924 & 1518 & 31,924 & 31,924 \\
\hline
\end{tabular}

Panel B: CEO power and safety and health incentives 
Table 9 (continued)

\begin{tabular}{|c|c|c|c|c|}
\hline & Incentive & Incentive & Incentive & Incentive \\
\hline \multirow[t]{2}{*}{ CEO duality } & 0.01 & 0.00 & & \\
\hline & $(0.86)$ & $(0.18)$ & & \\
\hline \multirow[t]{2}{*}{ CEO pay slice } & & & 0.02 & 0.00 \\
\hline & & & $(0.45)$ & $(0.09)$ \\
\hline \multirow[t]{2}{*}{ LnAge } & & 0.03 & & 0.03 \\
\hline & & $(0.61)$ & & $(0.58)$ \\
\hline \multirow[t]{2}{*}{ LnTenure } & & -0.01 & & $-0.01 *$ \\
\hline & & $(-1.62)$ & & $(-1.66)$ \\
\hline \multirow[t]{2}{*}{ Female CEO } & & 0.04 & & 0.04 \\
\hline & & $(0.64)$ & & $(0.64)$ \\
\hline \multirow[t]{2}{*}{ LnAssets } & & 0.01 & & 0.01 \\
\hline & & $(1.41)$ & & $(1.41)$ \\
\hline \multirow[t]{2}{*}{ Leverage } & & $-0.08^{* *}$ & & $-0.08 * *$ \\
\hline & & $(-2.31)$ & & $(-2.32)$ \\
\hline \multirow[t]{2}{*}{ PPE/assets } & & $0.17 * *$ & & $0.17 * *$ \\
\hline & & $(2.14)$ & & $(2.13)$ \\
\hline \multirow[t]{2}{*}{ Sales/assets } & & -0.01 & & -0.01 \\
\hline & & $(-0.94)$ & & $(-0.94)$ \\
\hline \multirow[t]{2}{*}{ Capex/assets } & & -0.09 & & -0.09 \\
\hline & & $(-0.41)$ & & $(-0.42)$ \\
\hline \multirow[t]{2}{*}{ Market/book } & & $-0.01^{*}$ & & $-0.01 *$ \\
\hline & & $(-1.86)$ & & $(-1.87)$ \\
\hline \multirow[t]{2}{*}{ Constant } & $0.03 * * *$ & -0.21 & 0.02 & -0.21 \\
\hline & $(2.88)$ & $(-0.87)$ & $(1.34)$ & $(-0.84)$ \\
\hline Industry FE & NO & YES & NO & YES \\
\hline Year FE & NO & YES & NO & YES \\
\hline State FE & NO & NO & NO & NO \\
\hline R-squared & 0.001 & 0.177 & 0.000 & 0.177 \\
\hline Level & Firm-year & Firm-year & Firm-year & Firm-year \\
\hline Observations & 1518 & 1518 & 1518 & 1518 \\
\hline
\end{tabular}

This table contains Panel A and Panel B. Panel A reports the results for regressions where workplace injuries and illnesses (TCR) is regressed on Incentive and a set of control variables. TCR is the number of work-related injury and illness cases divided with the number of hours worked multiplied with 200,000. Incentive is an indicator variable taking the value 1 if the CEO's compensation is in some way connected to the TCR, and 0 otherwise. Panel B reports the results for linear probability regressions where Incentive is regressed on CEO power (CEO duality or CEO pay slice) and a set of control variables. CEO duality is an indicator variable taking the value 1 if the CEO of the firm is also the chairperson of the firm, and 0 otherwise. CEO pay slice is measured as the proportion of the aggregated firm's top-five executive compensation obtained by the CEO. We provide definitions of all control variables in Appendix in Table 10. $t$-statistics are presented in the parentheses and calculated from robust standard errors clustered at the firm-level

Coefficients marked with *, **, and $* * *$ are significant at $10 \%, 5 \%$, and $1 \%$ level, respectively

we have not been able to rule out, could be that powerful CEOs are using their influence to underreport workplace injuries and illnesses. A final limitation of our study is that we do not consider the magnitude of net welfare effects of reduced workplace injuries and illnesses. Thus, structurally powerful CEOs could be associated with rates of injuries and illnesses that are lower than what is optimal, which overall would not be desirable if the benefits are lower than the costs. Nevertheless, the positive impact of lower rates of injuries and illnesses is a benefit for all employees and firms in that it results in less pain and lower wage losses as well as less litigation, decreased insurance premiums, and less negative publicity. 


\section{Appendix}

See Table 10.

Table 10 Variable definitions

\begin{tabular}{|c|c|c|}
\hline Variable & Description & Source \\
\hline TCR & $\begin{array}{l}\text { The number of injury and illness cases in a given establishment-year divided by the number of } \\
\text { hours worked by all employees in the establishment and multiplied by } 200,000\end{array}$ & OSHA \\
\hline DAW & $\begin{array}{l}\text { The days away from work and days spent on transfers in a given establishment-year divided by } \\
\text { the number of hours worked by all employees in the establishment and multiplied by } 200,000\end{array}$ & OSHA \\
\hline DCR & $\begin{array}{l}\text { The deaths in a given establishment-year divided by the number of hours worked by all employ- } \\
\text { ees in the establishment and multiplied by } 200,000\end{array}$ & OSHA \\
\hline CEO duality & $\begin{array}{l}\text { Indicator variable, taking the value } 1 \text { if the CEO is either president or chairperson of the firm } \\
\text { and } 0 \text { otherwise }\end{array}$ & ExecuComp \\
\hline CEO pay slice & The proportion of the aggregated firm's top-five executive compensation obtained by the CEO & ExecuComp \\
\hline LnAge & Natural logarithm of the CEO age & ExecuComp \\
\hline LnTenure & Natural logarithm of $1+$ the number of years the CEO has held the current position & ExecuComp \\
\hline Female CEO & Indicator variable, taking the value 1 if the $\mathrm{CEO}$ is a female and 0 otherwise & ExecuComp \\
\hline Hours per employee & $\begin{array}{l}\text { Total number of annual hours worked in a given establishment divided by the number of } \\
\text { employees }\end{array}$ & OSHA \\
\hline Establishment size & $\begin{array}{l}\text { Natural logarithm of average number of employees working in a given establishment during the } \\
\text { year }\end{array}$ & OSHA \\
\hline LnAssets & Natural logarithm of firm's total assets (at) from previous year $(t-1)$ & Compustat \\
\hline Leverage & $\begin{array}{l}\text { Firm's short-term and long-term debt }(\mathrm{dlc}+\mathrm{dltt}) \text { current year }(t) \text { divided by total assets (at) } \\
\text { from previous year }(t-1)\end{array}$ & Compustat \\
\hline PPE/assets & $\begin{array}{l}\text { Firm's net property, plant, and equipment (ppent) current year }(t) \text { divided by total assets (at) } \\
\text { from previous year }(t-1)\end{array}$ & Compustat \\
\hline Sales/assets & Firm's sales (sale) current year $(t)$ divided by total assets (at) from previous year $(t-1)$ & Compustat \\
\hline Capex/assets & $\begin{array}{l}\text { Firm's capital expenditures (capx) current year }(t) \text { divided by total assets (at) from previous } \\
\text { year }(t-1)\end{array}$ & Compustat \\
\hline Market/book & $\begin{array}{l}\text { Firm's market value of assets current year }(t) \text { divided by total assets (at) from previous year } \\
(t-1) \text {. Market value of assets are market value (cshpri*prcc_f) plus total liabilities (lt) plus } \\
\text { liquidation value of preferred stock (pstkl) minus deferred tax liabilities (txdb) }\end{array}$ & Compustat \\
\hline Strike & $\begin{array}{l}\text { Indicator variable, taking the value } 1 \text { if the establishment was in a strike/lockout during the year } \\
\text { and } 0 \text { otherwise }\end{array}$ & OSHA \\
\hline Shutdown & $\begin{array}{l}\text { Indicator variable, taking the value } 1 \text { if the establishment was in a shutdown/layoff during the } \\
\text { year and } 0 \text { otherwise }\end{array}$ & OSHA \\
\hline Seasonal & $\begin{array}{l}\text { Indicator variable, taking the value } 1 \text { if the establishment employs seasonal employees and } 0 \\
\text { otherwise }\end{array}$ & OSHA \\
\hline Disaster & $\begin{array}{l}\text { Indicator variable, taking the value } 1 \text { if the establishment was affected by extreme weather/natu- } \\
\text { ral disasters during the year and } 0 \text { otherwise }\end{array}$ & OSHA \\
\hline NonCompChange & $\begin{array}{l}\text { Indicator variable, taking the value } 1(-1) \text { if the establishment state had an increase (decrease) } \\
\text { in non-compete enforceability and } 0 \text { otherwise }\end{array}$ & Ewens and Marx (2018) \\
\hline Founder & Indicator variable, taking the value 1 if the CEO is a founder of the firm and 0 otherwise & $\begin{array}{l}\text { Lee et al. (2017) and } \\
\text { manual collection }\end{array}$ \\
\hline Percentage CEO text & $\begin{array}{l}\text { The ratio of the number of characters spoken by the CEO during the conference calls during the } \\
\text { year to the number of characters spoken by all firm executives during the conference calls dur- } \\
\text { ing the year. The ratio is multiplied by } 100\end{array}$ & Li et al. (2014) \\
\hline Ivy League & $\begin{array}{l}\text { Indicator variable, taking the value } 1 \text { if the } \mathrm{CEO} \text { has gradated (B. Sc., M. Sc, MBA, PhD) from } \\
\text { an Ivy League school and } 0 \text { otherwise }\end{array}$ & Manual collection \\
\hline Different state & $\begin{array}{l}\text { Indicator variable, taking the value } 1 \text { if the establishment is located in a different state than the } \\
\text { corporate headquarters, and } 0 \text { otherwise }\end{array}$ & OSHA and Compustat \\
\hline Incentive & $\begin{array}{l}\text { Indicator variable, taking the value } 1 \text { for years where the } \mathrm{CEO} \text { had compensation tied to the } \\
\text { injury and illness frequency and } 0 \text { otherwise }\end{array}$ & Incentive Lab \\
\hline
\end{tabular}


Acknowledgements We thank Section Editor Alexander Newman and two anonymous reviewers, Michael Dorff, Timo Korkeamäki, Mikko Leppämäki (discussant), Greg Shailer, Andy Stark, Toni Sundqvist, and conference and seminar participants at the 2018 Finnish Graduate School of Finance Winter Workshop, the 2019 Annual Conference of the British Accounting and Finance Association, the 2019 Finance, Risk and Accounting Perspectives Conference, and the 2020 Virtual Arthur seminar for valuable comments and suggestions. We also thank Dave Schmidt from the Occupational Safety and Health Administration, Office of Statistical Analysis for providing us the data on workplace safety and health. The authors gratefully acknowledge the funding from Liikesivistysrahasto, Suomen Arvopaperimarkkinoiden Edistämissäätio and Society of Swedish Literature in Finland. Part of this paper was written while Jesper Haga was visiting UNSW Sydney, Fredrik Huhtamäki was visiting Texas A\&M University, and Dennis Sundvik was visiting Pennsylvania State University and University of Technology Sydney. All errors are our own.

Funding Open Access funding provided by Hanken School of Economics.

\section{Compliance with Ethical Standards}

Conflict of interest The authors declare that they have no conflict of interest.

Open Access This article is licensed under a Creative Commons Attribution 4.0 International License, which permits use, sharing, adaptation, distribution and reproduction in any medium or format, as long as you give appropriate credit to the original author(s) and the source, provide a link to the Creative Commons licence, and indicate if changes were made. The images or other third party material in this article are included in the article's Creative Commons licence, unless indicated otherwise in a credit line to the material. If material is not included in the article's Creative Commons licence and your intended use is not permitted by statutory regulation or exceeds the permitted use, you will need to obtain permission directly from the copyright holder. To view a copy of this licence, visit http://creativecommons.org/licenses/by/4.0/.

\section{References}

Abernethy, M. A., Kuang, Y. F., \& Qin, B. (2015). The influence of CEO power on compensation contract design. Accounting Review, 90(4), 1265-1306.

Adams, R. B., Almeida, H., \& Ferreira, D. (2005). Powerful CEOs and their impact on corporate performance. Review of Financial Studies, 18(4), 1403-1432.

Albuquerque, R., Koskinen, Y., \& Zhang, C. (2019). Corporate social responsibility and firm risk: Theory and empirical evidence. Management Science, 65(10), 4451-4949.

Allen, M. P., \& Panian, S. K. (1982). Power, performance, and succession in the large corporation. Administrative Science Quarterly, 27, 538-547.

Amernic, J., \& Craig, R. (2017). CEO speeches and safety culture: British Petroleum before the Deepwater Horizon disaster. Critical Perspectives on Accounting, 47(1), 61-80.

Barkema, H. G., \& Pennings, J. M. (1998). Top management pay: Impact of overt and covert power. Organization Studies, 19(6), 975-1003.

Barling, J., Loughlin, C., \& Kelloway, E. K. (2002). Development and test of a model linking safety-specific transformational leadership and occupational safety. Journal of Applied Psychology, 87(3), 488-496.

Barnea, A., \& Rubin, A. (2010). Corporate social responsibility as a conflict between shareholders. Journal of Business Ethics, 97(1), 71-86.

Bebchuk, L. A., \& Fried, J. M. (2004). Executive compensation at Fannie Mae: A case study of perverse incentives, nonperformance pay, and camouflage. Journal of Corporation Law, 30, 807-822.

Bebchuk, L. A., Cremers, K. J. M., \& Peyer, U. C. (2011). The CEO pay slice. Journal of Financial Economics, 102(1), 199-221.

Boden, L. (2005). Running on empty: Families, time, and workplace injuries. American Journal of Public Health, 95(11), 1894-1897.

Boden, L., \& Galizzi, M. (1999). Economic consequences of workplace injuries and illnesses: Lost earnings and benefit adequacy. American Journal of Industrial Medicine, 36(5), 487-503.

Boden, L. I., \& Ozonoff, A. L. (2008). Capture-recapture estimates of nonfatal workplace injuries and illnesses. Annals of Epidemiology, 18(6), 500-506.

Bradley, D., Mao, C., \& Zhang, C. (2019). Does analyst coverage affect workplace safety? AFA 2019 Atlanta Meetings Paper. Retrieved January 1, 2021 from https://ssrn.com/abstract=3313851.

Bradley, D., Mao, C. X., \& Zhang, C. D. (2018). Do corporate taxes affect workplace safety? Fox School of Business Research Paper No. 18-036. Retrieved January 1, 2021 from https://ssrn.com/abstr act $=3223949$.

Cartwright, D. (1965). Influence, Leadership, Control. In J. G. March (Ed.), Handbook of organizations (pp. 1-47). Chicago, IL: Rand McNally.

Caskey, J., \& Ozel, N. B. (2017). Earnings expectations and employee safety. Journal of Accounting and Economics, 63(1), 121-141.

Cantor, D. (2008). Workplace safety in the supply chain: A review of the literature and call for research. International Journal of Logistics Management, 19(1), 65-83.

Christensen, H. B., Floyd, E., Liu, L. Y., \& Maffett, M. (2017). The real effects of mandated information on social responsibility in financial reports: Evidence from mine-safety records. Journal of Accounting and Economics, 64(2-3), 284-304.

Christian, M., Bradley, J., Wallace, J., \& Burke, M. (2009). Workplace safety: A meta-analysis of the roles of person and situation factors. Journal of Applied Psychology, 94(5), 1103-1127.

Choo, A., \& Grabowski, M. (2018). Linking workplace safety to operational disruptions: A moderated mediation analysis in commerical vessels. Journal of Business Logistics, 39(4), 282-298.

Chu, J., Dechow, P. M., Hui, K. W., \& Wang, A. Y. (2019). Maintaining a reputation for consistently beating earnings expectations and the slippery slope to earnings manipulation. Contemporary Accounting Research, 36(4), 1966-1998.

Chung, K. H., \& Zhang, H. (2011). Corporate governance and institutional ownership. Journal of Financial and Quantitative Analysis, 46(1), 247-273.

Cohn, J. B., \& Wardlaw, M. I. (2016). Financing constraints and workplace safety. Journal of Finance, 71(5), 2017-2058.

Cronqvist, H., Heyman, F., Nilsson, M., Svaleryd, H., \& Vlachos, J. (2009). Do entrenched managers pay their workers more? Journal of Finance, 64(1), 309-339.

Dahl, R. A. (1957). The concept of power. Behavioral Science, 2(3), 201-215.

Eidelson, J., \& Hull, D. (2019). Tesla staff's lost workdays triple on factory injuries, illness. Bloomberg. Retrieved January 1, 2021 from https://www.bloomberg.com/news/articles/2019-03-19/tesla-facto ry-injuries-idled-workers-three-times-as-much-in-2018.

El-Khatib, R., Fogel, K., \& Jandik, T. (2015). CEO network centrality and merger performance. Journal of Financial Economics, 116(2), 349-382. 
EU-OSHA. (2017). Work-related accidents and injuries cost EU €476 billion a year according to new global estimates. Retrieved January 1, 2021 from https://osha.europa.eu/en/printpdf/12566.

Evans, W. (2019). Ruthless quotas at Amazon are maiming employees. The Atlantic. Retrieved January 1, 2021 from https://www.theat lantic.com/technology/archive/2019/11/amazon-warehouse-repor ts-show-worker-injuries/602530/.

Ewens, M., \& Marx, M. (2018). Founder replacement and startup performance. Review of Financial Studies, 31(4), 1532-1565.

Fabrizi, M., Mallin, C., \& Michelon, G. (2014). The role of CEO's personal incentives in driving corporate social responsibility. Journal of Business Ethics, 124(2), 311-326.

Faccio, M., Marchica, M. T., \& Mura, R. (2016). CEO gender, corporate risk-taking, and the efficiency of capital allocation. Journal of Corporate Finance, 39, 193-209.

Fama, E. F., \& Jensen, M. C. (1983). Separation of ownership and control. Journal of Law and Economics, 26(2), 301-325.

Finkelstein, S. (1992). Power in top management teams: Dimensions, measurement, and validation. Academy of Management Journal, 35(3), 505-538.

Finkelstein, S., \& D'aveni, R. A. (1994). CEO duality as a doubleedged sword: How boards of directors balance entrenchment avoidance and unity of command. Academy of Management Journal, 37(5), 1079-1108.

Friedman, M. (1970). A theoretical framework for monetary analysis. Journal of Political Economy, 78(2), 193-238.

Galinsky, A. D., Magee, J. C., Gruenfeld, D. H., Whitson, J. A., \& Liljenquist, K. A. (2008). Power reduces the press of the situation: implications for creativity, conformity, and dissonance. Journal of Personality and Social Psychology, 95(6), 1450.

Galizzi, M., \& Zagorsky, J. (2009). How do on-the-job injuries and illnesses impact wealth? Labour Economics, 16(1), 26-36.

Gyekye, S., \& Salminen, S. (2009). Educational status and organizational safety climate: Does educational attainment influence workers' perceptions of workplace safety? Safety Science, 47(1), $20-28$.

Hambrick, D. C. (1981). Environment, strategy, and power within top management teams. Administrative Science Quarterly, 26, 253-275.

Hillman, A. J., \& Klein, G. D. (2001). Shareholder value, stakeholder management, and social issues: What's the bottom line? Strategic Management Journal, 22, 125-139.

Hirsh, J. B., Lu, G. L., \& Galinsky, A. D. (2018). Moral utility theory: Understanding the motivation to behave (un)ethically. Research in Organizational Behavior, 38(1), 43-59.

Huang, Y. H., Chen, J. C., DeArmond, S., Cigularov, K., \& Chen, P. Y. (2007). Roles of safety climate and shift work on perceived injury risk: A multi-level analysis. Accident Analysis \& Prevention, 39(6), 1088-1096.

International Labor Organization. (2017). Accurate data will help to save lives. Retrieved January 1, 2021 from https://www.ilo.org/ global/about-the-ilo/how-the-ilo-works/ilo-director-general/state ments-and-speeches/WCMS_551573/lang--en/index.htm.

Jensen, M. C., \& Meckling, W. H. (1976). Theory of the firm: Managerial behavior, agency costs and ownership structure. Journal of Financial Economics, 3(4), 305-360.

Jiraporn, P., \& Chintrakarn, P. (2013). How do powerful CEOs view corporate social responsibility (CSR)? An empirical note. Economics Letters, 119(3), 344-347.

Jizi, M. I., Salama, A., Dixon, R., \& Stratling, R. (2014). Corporate governance and corporate social responsibility disclosure: Evidence from the US banking sector. Journal of Business Ethics, 125(4), 601-615.

Joshi, P. D., \& Fast, N. J. (2013). Power and reduced temporal discounting. Psychological Science, 24(4), 432-438.
Kaptein, M. (2008). Developing a measure of unethical behavior in the workplace: A stakeholder perspective. Journal of Management, 34(5), 978-1008.

Kelloway, E. K., Mullen, J., \& Francis, L. (2006). Divergent effects of transformational and passive leadership on employee safety. Journal of Occupational Health Psychology, 11(1), 76.

Kniesner, T. J., \& Leeth, J. D. (2014). Regulating occupational and product risks. In M. J. Machina \& W. K. Viscusi (Eds.), Handbook of the economics of risk and uncertainty (Vol. 1, pp. 493-600). Amsterdam: Elsevier.

Landier, A., Nair, V. B., \& Wulf, J. (2009). Trade-offs in staying close: Corporate decision making and geographic dispersion. Review of Financial Studies, 22(3), 1119-1148.

Lee, J. M., Hwang, B. H., \& Chen, H. (2017). Are founder CEOs more overconfident than professional CEOs? Evidence from S\&P 1500 companies. Strategic Management Journal, 38(3), 751-769.

Leigh, J. P. (2011). Economic burden of occupational injury and illness in the United States. The Milbank Quarterly, 89(4), 728-772.

Leigh, J. P., \& Marcin, J. P. (2012). Workers' compensation benefits and shifting costs for occupational injury and illness. Journal of Occupational and Environmental Medicine, 54(4), 445-450.

Li, F., Li, T., \& Minor, D. (2016). CEO power, corporate social responsibility, and firm value: A test of agency theory. International Journal of Managerial Finance, 12(5), 611-628.

Li, F., Minnis, M., Nagar, V., \& Rajan, M. (2014). Knowledge, compensation, and firm value: An empirical analysis of firm communication. Journal of Accounting and Economics, 58(1), 96-116.

Li, M., Lu, Y., \& Phillips, G. M. (2019). CEOs and the product market: when are powerful CEOs beneficial? Journal of Financial and Quantitative Analysis, 54(6), 2295-2326.

Morse, A., Nanda, V., \& Seru, A. (2011). Are incentive contracts rigged by powerful CEOs? Journal of Finance, 66(5), 1779-1821.

Mullen, J. (2005). Testing a model of employee willingness to raise safety issues. Canadian Journal of Behavioural Science, 37(4), 273-282.

Muttakin, M. B., Khan, A., \& Mihret, D. G. (2018). The effect of board capital and CEO power on corporate social responsibility disclosures. Journal of Business Ethics, 150(1), 41-56.

OECD. (2017). Industrial disputes. Retrieved January 1, 2021 from https://www.oecd.org/els/emp/Industrial-disputes.pdf.

Ohnsman, A. (2019). Inside Tesla's Model 3 factory, where safety violations keep rising. Bloomberg. Retrieved January 1, 2021 from https://www.forbes.com/sites/alanohnsman/2019/03/01/tesla-safet y-violations-dwarf-big-us-auto-plants-in-aftermath-of-musks -model-3-push/.

OSHA. (2018). Employee-reported workplace injuries and illnesses. Retrieved January 1, 2021 from https://www.bls.gov/news.relea se/archives/osh_11082018.pdf.

Pagano, M., \& Volpin, P. F. (2005). Managers, workers, and corporate control. Journal of Finance, 60(2), 841-868.

Petitta, L., Probst, T. M., \& Barbaranelli, C. (2017). Safety culture, moral disengagement, and accident underreporting. Journal of Business Ethics, 141(3), 489-504.

Pfeffer, J. (2010). Power: Why some people have it-and others don't. New York: Harper Collins.

Rosenman, K. D., Kalush, A., Reilly, M. J., Gardiner, J. C., Reeves, M., \& Luo, Z. (2006). How much work-related injury and illness is missed by the current national surveillance system? Journal of Occupational and Environmental Medicine, 48(4), 357-365.

Sainato, M. (2020). 'I'm not a robot', Amazon workers condemn unsafe, grueling work conditions at warehouse. The Guardian. Retrieved January 1, 2021 from https://www.theguardian.com/ technology/2020/feb/05/amazon-workers-protest-unsafe-gruel ing-conditions-warehouse.

Serfling, M. A. (2014). CEO age and the riskiness of corporate policies. Journal of Corporate Finance, 25, 251-273. 
Smith, L. C., Smith, M., \& Ashcroft, P. (2011). Analysis of environmental and economic damages from British Petroleum's Deepwater Horizon oil spill. Albany Law Review, 74(1), 563-585.

Sparks, J. R., \& Hunt, S. D. (1998). Marketing researcher ethical sensitivity: Conceptualization, measurement, and exploratory investigation. Journal of Marketing, 62(2), 92-109.

Tang, J., Crossan, M., \& Rowe, W. G. (2011). Dominant CEO, deviant strategy, and extreme performance: The moderating role of a powerful board. Journal of Management Studies, 48(7), 1479-1504.

Thibaut, J. W., \& Kelley, H. H. (1959). The social psychology of groups. New York: Wiley.

Tucker, S., Ogunfowora, B., \& Ehr, D. (2016). Safety in the c-suite: How chief executive officers influence organizational safety climate and employee injuries. Journal of Applied Psychology, 101(9), 1228-1239.

Viscusi, W. K. (2010). The heterogeneity of the value of statistical life: Introduction and overview. Journal of Risk and Uncertainty, 40, $1-13$.

Wagner, R. (2019). Have we learned the Alcoa 'Keystone Habit' lesson? Forbes. Retrieved January 1, 2021 from https://www.forbe s.com/sites/roddwagner/2019/01/22/have-we-learned-the-alcoa -keystone-habit-lesson/.

Walls, J. L., \& Berrone, P. (2017). The power of one to make a difference: How informal and formal CEO power affect environmental sustainability. Journal of Business Ethics, 145(2), 293-308.
Wokutch, R. (1990). Corporate social responsibility Japanese style. Academy of Management Perspectives, 4(2), 56-74.

Wong, J. (2018). Tesla workers say they pay the price for Elon Musk's big promises. The Guardian. Retrieved January 1, 2021 from https ://www.theguardian.com/technology/2018/jun/13/tesla-workerspay-price-elon-musk-failed-promises.

Wu, C., Li, N., \& Fang, D. (2017). Leadership improvement and its impact on workplace safety in construction projects: A conceptual model and action research. International Journal of Project Management, 35(8), 1495-1511.

Xia, N., Wang, X., Griffin, M., Wu, C., \& Liu, B. (2017). Do we see how they perceive risk? An integrated analysis of risk perception and its effect on workplace safety behaviour. Accident Analysis \& Prevention, 35(8), 1495-1511.

Yuan, X., Xu, Y., \& Li, Y. (2020). Resource depletion perspective on the link between abusive supervision and safety behaviors. Journal of Business Ethics, 162, 213-228.

Zierold, K. M., Welsh, E. C., \& McGeeney, T. J. (2012). Attitudes of teenagers towards workplace safety training. Journal of Community Health, 37(6), 1289-1295.

Publisher's Note Springer Nature remains neutral with regard to jurisdictional claims in published maps and institutional affiliations. 